\title{
GRANDES FAMÍLIAS E ELITE 'PROFISSIONAL' NA MEDICINA NO BRASIL
}

\author{
IMPORTANT FAMILIES AND THE 'PROFESSIONAL' \\ ELITE WITHIN BRAZILIAN MEDICINE
}

Odaci Luiz Coradini*

\begin{abstract}
CORADINI, O. L.: 'Important families and the professional elite within brazilian medicine'. Historia, Ciências, Satide - Manguinhos, III (3) 425-466, Nov. 1996-Feb. 1997.

The article portrays the social and ideological grounds that tunderpin selection of Brazil's medical elite. It introduces a conceptual discussion regarding relations of reciprocity within official Brazilian institutions, using the National Academy of Medicine as its empirical basis. Secondly, using as a reference some representative careers of members of this my at different moments of its existence, the article endeavors to characterize both a general standard of conception and social and political practices. Lastly, it explores the significance of school diplomas as a means of upward social mobility and for recruiting Brazil's elites.
\end{abstract}

KEYWORDS: medical elite, professional career, medical institutions, family origin, political power.

-Mestre em ciência política pelo DCP/UFMG, doutor em antropologia social pelo PPGAS/ Museu Nacional/UFRJ e professor do IFCH/ UFRS. Av. Bento Goncalves, 9500 91501-970 Porto Alegre - RS
Este artigo, com título inspirado em Saint-Martin (1980), versa sobre a "formação de elites" e almeja alcançar três objetivos. Primeiro, introduzir uma discussão conceitual sobre as relações de reciprocidade em instituições oficiais no Brasil, a partir do caso da Academia Nacional de Medicina. Segundo, valendo-se de trajetórias representativas dos componentes desta academia, em diferentes períodos de sua existência, o artigo procura localizar um padrão geral nas relações e práticas sociais e políticas que, a despeito das vicissitudes históricas, se prolonga até o final do período considerado (1960-70). Examina, por fim, os diferentes significados do título escolar, enquanto recurso para ascensão social e seleção de elites no Brasil, apontando suas relações com a alegada 'crise' conseqüente à expansão e diversificação recente do mercado escolar.

\section{As bases sociais e ideológicas da seleção da elite médica}

Alguns desafios conceituais se impõem à análise dos princípios e critérios que numa sociedade 'periférica' presidem ao recrutamento e seleção da elite de determinada 'profissão', cuja caução oficial são, sobretudo, os títulos escolares. Se por um lado não se trata de uma situação meramente 'tradicional', por outro está em pauta 
uma elite culturalmente dominante numa sociedade periférica e 'importadora' das ideologias, filosofias e tecnologias médicas dos países 'centrais'. Isso resulta em algumas dificuldades para a utilização de esquemas analíticos formulados com base em outros referenciais empíricos.

A obra de Bourdieu fornece o principal marco conceitual da presente investigação. Em seu trabalho mais importante, cujo referencial empírico é uma sociedade 'não-ocidental' (Argélia), estabelece uma oposição básica. De um lado, uma situação que se caracteriza pela inexistência de mercado estruturado e instituições que garantam a equivalência entre títulos. Conseqüentemente, a acumulação das diferentes formas de capital (econômico, simbólico etc.) está centrada em estratégias e relações de reciprocidade, estratégias e relações personificadas (Bourdieu, 1980a, pp. 209-31). Por outro lado, a esta situação se opõe a existência de uma estrutura que garante a equivalência entre os títulos de cada campo (títulos de propriedade econômica e escolar, entre outros), independentemente do agente social que tem a posse deles (idem, ibidem, pp. 227-30). Na primeira situação, sem estrutura que garanta a equivalência dos títulos e da posição social correspondente, as estratégias dos agentes estão voltadas para a acumulação do capital simbólico personificado, condição de garantia das demais formas de capital.

Em outros trabalhos referidos empiricamente à França, aborda este tipo de relações sociais baseadas na reciprocidade através do conceito de capital social (idem, 1980b). Mas em trabalhos concernentes especificamente às formas e estratégias de reprodução social centradas na 'família' ou na escolarização (idem, 1989, 1984a), tanto a noção de capital social como seus correlatos (por exemplo, nepotismo e cooptação) aparecem de modo residual e não estruturante. Sintomaticamente, o capital social torna-se central para a apreensão das estratégias de reprodução social, quando são tomados como objeto de estudo componentes de grandes famílias oriundas da antiga nobreza que utilizam os recursos decorrentes destas origens para a ascensão profissional. Observa-se isso no trabalho de Saint Martin (1980). Em síntese, as investigações de Bourdieu e sua equipe sobre as elites com base na titulação escolar, na França, buscam, sobretudo, explicitar os fundamentos da ideologia meritocrática, confrontando-a com outros determinantes sociais (Bourdieu e Saint Martin, 1987), ou senão revelando seu amálgama com outras sociodicéias (Charle, 1987), como o princípio da antiguidade.

Aquilo que aparece como secundário nos trabalhos relativos à França sequer é admissível, oficialmente, pelos agentes sociais. Sua explicitação requer, portanto, a releitura da documentação composta de biografias (Saint Martin, 1980). Já entre as elites mé- 
dicas do Brasil, as relações com base na reciprocidade não apenas são constituintes do grupo, como são oficialmente admitidas e até proclamadas com solenidade. Por outro lado, a definição do capital social - "o conjunto dos recursos atuais ou potenciais que estão vinculados à posse de uma rede durável de relaçôes mais ou menos institucionalizadas de interconhecimento e interreconhecimento" (Bourdieu, 1980b, p. 2) - é por demais geral para se apreender a diversidade sociológica das relações de reciprocidade em vigor, tais como o parentesco, a 'amizade' e a patronagem profissional e política.

Outra vertente, de origem predominantemente anglo-saxônica, sugere todo um arsenal conceitual para a apreensão de relações e estruturas sociais com base na reciprocidade e, especificamente, no clientelismo. É o caso, por exemplo, de noções como "alianças diádicas", "clientelismo como addenda", "amizade instrumental", "redes", "quase-grupos", "facções", "segmentaridade" etc. (Schmidt et al., 1977; Banton, 1980; Gellner et al., 1985, entre outros). Nesse caso, no entanto, ainda se está longe de formular uma teoria que integre o conjunto de conceitos propostos e, ademais, resolva os problemas de ordem metodológica que sua aplicação nas ditas "sociedades complexas" suscitam. Assim, se Wolf (1980, pp. 1920) qualifica as relações de reciprocidade com base na "amizade instrumental" como "intersticiais" nas estruturas formais de poder, o caso em pauta envolve uma instituição oficial, em que o intersticial encobre o conjunto das relações e práticas sociais que a constituem. Estas dificuldades talvez decorram do desenvolvimento deste tipo de abordagem, voltada inicialmente para as sociedades ditas 'primitivas'. Os estudos mais recentes visando a chamada Europa Mediterrânea continuaram a privilegiar grupos "periféricos" (Davis, 1983). Por outro lado, pode ser importante, mas apenas como proposição geral, a sugestão de Badie e Hermet (1990, p. 257): "não é suficiente definir (clientelismo na América Latina) de maneira clássica como uma aliança diádica vertical", sendo necessário "ultrapassar a simetria funcional um pouco ilusória contida nesta definição, para apreender o fenômeno em sua dimensão mais ampla de agenciamento do poder do Estado e seu monopólio por uma elite civil hostil à sua lógica centralizadora". Continuam em aberto os problemas metodológicos e conceituais, a começar pelas relações entre "neópatrimonialismo" e "clientelismo".

Seja como for, permanecem válidas algumas propostas muito sugestivas para explicitar as bases sociais das relações de reciprocidade, tais como parentesco, "amizade instrumental", patronagem e segmentaridade (Wolf, 1980; Boissevain, 1966). Estas noções - que dão pistas relativas à continuidade histórica de suas bases culturais (Cole e Wolf, 1974) — podem ser utilizadas de modo complementar à de capital social (Bourdieu, 1980b). 
Mas o tema em pauta - o recrutamento e a seleção da elite médica no Brasil - envolve outros problemas conceituais não resolvidos. Principalmente este: trata-se de uma elite 'profissional' que se escora, ao menos formalmente, na titulação escolar, numa sociedade que não tem a profissão como seu principal princípio de hierarquização e que, além disso, 'importa' tanto a tecnologia médica como o conjunto das filosofias médicas e políticas e dos modelos institucionais correspondentes. $\mathrm{O}$ problema resicle exatamente na explicitação do sentido e dos efeitos desta 'importação', visto que os usos sociais do que é importado se modificam vis-à-vis às condições sociais em que são geradas as filosofias e tecnologias médicas, institucionais e políticas. Assim, por exemplo, se a geração da medicina francesa tem relação direta com as condições políticas e ideológicas resultantes de processos históricos pós-revolucionários (Léonard, 1981), como são apropriados os produtos desses processos em sociedades como a brasileira no mesmo período?

Como dissemos, os trabalhos de Bourdieu e sua equipe (sobretudo 1989, 1984a, pp. 61-88; Bourdieu e Saint Martin, 1987) revelam múltiplos princípios de legitimação e hierarquização dos campos acadêmico, escolar e científico. Porém, o eixo básico é sempre balizado por dois pólos. De um lado, determinantes associados mais diretamente ao capital escolar ou científico, com seu etbos e suas regras próprias, e correlações com origens e trajetórias sociais que predispõem a estratégias de investimentos orientadas nesse sentido. De outro, princípios de legitimação e hierarquização decorrentes não tanto do capital escolar, mas sobretudo da origem e posição social e respectivas relações com a cultura dominante e o poder (econômico, político, cultural etc.). As relações com o campo educacional pautam-se, aqui, por um uso instrumental de seus produtos, mais do que pela inserção em sua racionalidade e ethos próprios. No estudo da elite médica brasileira verifica-se que este segundo pólo, menos escolar e mais 'mundano', ou de consagração social, é parte estrutural do conjunto de princípios de legitimação que concorrem para as definições e a hierarquização do campo escolar e/ou científico. Os dois pólos que compõem o eixo básico do campo são interdependentes, mas, no caso em pauta, o que representa o ethos e as regras próprias da racionalidade escolar está ausente. Os produtos e títulos escolares são usados mais para a ocupação de posições em outras esferas de poder.

As condições se modificam completamente quando se tem a importação de filosofias e tecnologias médicas, bem como de suas regras institucionais de controle e reprodução. Apenas um dos pólos se faz, então, presente: a utilização prática dos resultados da geração de filosofias e tecnologias, visto que não são impor- 
tados o ethos, as regras, as condições, em síntese, de sua geração. Mas o principal problema é que as condições sociais e culturais do lugar diferem completamente. Sendo assim, a própria racionalidade ou lógica do consumo ou usos sociais destas filosofias e tecnologias médicas não são homólogas às dos países de origem das mesmas e, inclusive, os próprios significados do título escolar se modificam.

Isso remete ao problema dos efeitos da importação de filosofias e modelos por sociedades 'extra-ocidentais'. Badie e Hermet (1990, pp. 231-74) destacam a justaposição, o caráter "hỉbrido" que resulta desse processo, com hiperpolitização associada a tensões entre 'racionalidades' contraditórias, agravadas na América Latina pelo peso determinante do clientelismo. Porém, apesar da fertilidade analítica dessa abordagem, diversos problemas ficam em aberto. Em primeiro lugar, a dualidade não significa mera justaposição, mas um amálgama específico, difícil de ser apreendido e explicitado. Em segundo lugar, na situação compósita resultante, ainda que se possam aplicar as abordagens e o arsenal analítico forjados para outras realidades, a apreensão sempre é parcial. É o caso, por exemplo, da estrutura da "sociedade da corte" apresentada por Elias (1987): há algumas semelhanças entre o Império brasileiro e a corte francesa, mas elas são muito tênues. O mesmo se pode dizer, para citar mais um exemplo, de noções weberianas como patrimonialismo.

\section{Os condicionamentos sociais de três trajetórias profissionais bem-sucedidas}

Das centenas de componentes da Academia Nacional de Medicina que foram estudados, selecionei apenas três, cujas trajetórias abrangem o período que se estende do início da instituição, em 1829, até a década de 1980. Para evitar que as idiossincrasias ou peculiaridades de cada caso sejam confundidas com as condições mais gerais em que transcorreram estas trajetórias, sempre que possivel confrontei as informações relativas a elas com as do conjunto de acadêmicos contemporâneos.

Marcado patrimonialismo caracteriza as trajetórias profissionais e sociais que transcorreram no período imperial, especificamente José da Cruz Jobim é João Vicente Torres Homem. Já no caso de Pedro da Silva Nava, que pertence ao século $\mathrm{XX}$, mais que patrimonialismo ou relações diretas com agentes do poder político central, são suas inserções em determinadas esferas profissionais e das burocracias públicas que o conduzem à condição de componente da academia e, portanto, da elite médica nacional.

O principal a destacar é que, para além das mudanças no quadro político-institucional e nas respectivas esferas sociais que 
determinam as especificidades das trajetórias em pauta, o princípio básico que fornece os criterios de recrutamento da elite sempre foi o das relações sociais com base na reciprocidade, com toda a sua variedade de formas. Mesmo com a substituição da figura do imperador, referência central para a escolha e ascensão de elites, por um conjunto de esferas profissionais e sociais que tendem ao corporativismo no final do período considerado, as concepções relativas à profissão e à concessão de 'títulos' e postos, e a conseqüente consagração social, nunca deixaram de se pautar em relações personificadas com base na reciprocidade. A melhor maneira de se evidenciar isso é confrontando o elenco de títulos ostentados pelas biografias, inclusive os estritamente escolares e/ou profissionais, com as relações de reciprocidade subjacentes. Ou senão cotejando as situações de ruptura ou reconversão nas trajetórias, tais como o ingresso na escolarização elementar ou superior, na profissão, ou a sucessão de postos profissionais com as utilizações concomitantes de um ou mais conjuntos de relações particulares, ou seja, de reciprocidade, das quais provém o capital social. A única mudança significativa nesse padrão ocorre só no final do período considerado, com a expansão do ensino superior e o estabelecimento correlativo de regras despersonificadas para $o$ ingresso no mesmo.

As principais fontès utilizadas para o estudo do caso de Pedro da Silva Nava são fruto de suas atividades literárias de memorialista. Já as informações referentes a Jobim e a Torres Homem provêm de biografias elaboradas por admiradores que vieram depois. $\mathrm{O}$ interesse dos biógrafos por Jobim deve-se à sua proeminência política, ao fato de ser o patrono da cadeira $n^{2} 41$ da Academia de Medicina e de haver pertencido também à Sociedade Auxiliadora da Indústria Nacional, "à qual se deve a iniciativa da fundação do Instituto Histórico e Geográfico Brasileiro" (Fernandes, 1980, p. 249).

A 'fundação' da família Cruz (posteriormente Jobim) no Brasil resultou do processo de conquista militar do extremo Sul. O pai do Jobim em pauta era um militar português. Foi deslocado para os Açores, depois, por força das guerras com a Espanha na Bacia do Prata, acabou como tenente dos Dragões do Exército português, fixado em Rio Pardo (RS). Ao chegar ao Brasil, em 1780, estabeleceu relações com o príncipe regente, o qual, "sabedor da bravura com que se distinguira", concedeu-lhe como recompensa "uma sesmaria de campo, fazendo-o, mais tarde, juiz de Órfãos, cargo que exerceu até 1816, ano de sua morte. Nessa sesmaria, José Martins Jobim instalou uma estância de criação e nela vieram à luz os oito filhos dos seus dois matrimônios" (Fernandes, 1982, pp. 11-2). Trata-se, portanto, de uma familia de origem de militares-estancieiros, como é o caso da maior parte 
1 Possuo informações sobre nove dos 22 componentes da academia nascidos entre 1768 e 1802: dois são filhos de cirurgiōes, dois de laviadores, um de cirurgiãomor, um de negociante e um (Jobim) de médico militar e um de tenente dos Dragões. Para 14 dos 38 nascidos entre 1835 e 1850, tem-se cinco filhos de médicos, cinco de militares de altas patentes, $u m$ de farmacêutico, um de desembargador, um de magistrado e um de um indefinido "doutor". Quanto a 18 dos 57 nascidos entre 1895 e 1904 , dez são filhos de médi$\cos$, dois de juízes, dois de doutores, um de proprietário de escola, um de advogaclo e dois de funcionários públicos. Sobre a reduzida pertinência da profissão do pai como indicador de origens sociais, ver Coradini (1994, pp. 110-38). da classe dominante regional do período. Quanto às origens sociais, José da Cruz Jobim, um dos filhos de José Martins, não destoa dos demais componentes da Academia de Medicina. A principal semelhança são as relações diretas de sua família com os agentes do poder político central e a origem militar, que é também a das famílias de diversos acadêmicos. A principal diferença é que sua família ainda não possuía nenhuma relação com a medicina, ao contrário do que acontecia com boa parte dos demais. ${ }^{1}$ José da Cruz Jobim foi o iniciador do clã médico.

Ao contrário da grande maioria de seus conterrâneos, lê-se numa biografia: "desde cedo ocupados com armas, seria o menino José, como era do desejo de seu pai, destinado à medicina". Foi, então, enviado a uma instituição religiosa da Corte, o Seminário São José, já que no período, por ausência de um aparelho educacional formal, este tipo de instituição era o que oferecia maior disciplina e melhor educação básica. $\mathrm{O}$ afamado seminário foi o primeiro ambiente para o estabelecimento de laços que se prolongaram na trajetória posterior: ali teve como "condiscípulo, entre outros que se destacariam na vida nacional, Joaquim José Rodrigues Torres, futuro visconde de Itaboraí, mais tarde seu contemporâneo no Senado do Império" (idem, ibidem, p. 12).

O primeiro grande recurso em prol de sua titulação em medicina foi a utilização das relações de seu pai com o imperador. Depois que ficou órfão dele, o "tio Antônio o acudiria, sustentandolhe os estudos até completar o curso ginasial". Matriculou-se em seguida na Universidade de Montpellier e se transferiu depois para a Faculdade de Medicina de Paris. Com a morte do tio e o nascimento de um filho natural nesta última cidade (o qual também iria se formar em medicina, tornando-se capitão do Corpo de Saúde do Exército no Brasil), a continuidade dos estudos ficou ameaçada pelas dificuldades financeiras. Jobim recorreu, então, ao imperador Pedro I, "que o atende em atenção aos serviços prestados pelo pai à Coroa nas campanhas do Sul" (idem, 1980, p. 249). Ao retornar à Europa, visitou o local de origem dos ancestrais, Santa Cruz Jobim, em Portugal, e resolveu incorporar "Jobim̄" ao sobrenome, "no que foi seguido pelos demais parentes de descendência brasileira". A mesma iniciativa fora tomada no lado materno: o avô havia substituído o sobrenome "Águeda por Fortes, atendendo a que na Vila do Rio Pardo todos assim chamavam os da família em virtude da robusta compleição que apresentavam" (idem, 1982, p. 13).

Com o diploma de "bacharel em ciências físicas" e "o grau de doutor em medicina", obtido em 1828, Jobim foi um dos poucos médicos (ou "físicos") a integrar o quadro original da Academia Imperial de Medicina, numa época em que predominavam os "cirurgiões" (Santos Filho, 1991, 1967). Porém, não foi só o título 
2 Descle o fim do século XVIII, a maioria dos estudantes brasileiros, seduzidos pelas icléias da revolução francesa, preferia a Universidade de Montpellier à de Coimbra, onde reinavam o "reacionarismo" e atraso" (Fernandes, 1980, pp. 249-50).

3 Sobre a formação da academia e a influência da Academia Francesa, ver IHGB (1942, pp. 625-31). Descrição histórica geral da influência francesa na medicina $e$ farmácia no Brasil consta em Araújo (s.d.). Weisz (1988a, 1988b) analisa as trajetórias sociais clos componentes da Academia Francesa e a ideologia meritocrática entre os mesmos. que trouxe de Paris. Em seu retorno, passou a contar com as relações estabelecidas lá com outros médicos, com os modelos" institucionais de ensino e exercício da profissão e com as ideologias políticas "pós-revolucionárias". ${ }^{2}$ Tudo isso contribuiu para sua ascensão profissional como médico, diretor, político, conselheiro do imperador e em mais algumas esferas de atividades.

Logo após o regresso ao Brasil, em 1829, Jobim passou a ser médico e chefe de enfermaria no Hospital da Santa Casa da Misericórdia. Instalou também um consultório clínico. Alguns anos depois, foi admitido por concurso como "lente proprietário" de medicina legal na faculdade de medicina que surgia no Rio de Janeiro. Porém, dependeram não destas, mas de outras atividades, os principais títulos que conquistou posteriormente. Uma das primeiras foi a fundação da Academia Imperial de Medicina, para a qual se utilizou das relações com outros médicos e com os modelos em voga durante a estada na França. Segundo Fernandes (1980, p. 251):

"No decorrer do seu curso médico ... tivera oportunidade de assistir às reuniões da Academia de Medicina de Paris, fundada em $1820 \ldots$, o que muitas vezes fizera em companhia de Soares de Meireles ... . De lá trouxera a idéia de fundar aqui uma associação médica nos mesmos moldes da parisiense, tal como se evidencia pela semelhança de ambos os estatutos. A idéia logo se tornaria realidade pela feliz circunstância de ser a enfermaria de Cruz Jobim vizinha da de Simoni ... . Em seguida, procuraram a cooperação de dois colegas franceses aqui domiciliados, os doutores Xavier Sigaud e Jean Maurice Faivre."

Ampliados, assim, os contatos, e solicitado o "reconhecimento oficial" das entidades imperiais, foi formada a primeira diretoria da Sociedade de Medicina do Rio de Janeiro que, em 1835, se transformou em Academia Imperial de Medicina. Com 27 anos de idade, Jobim era o mais novo do grupo dos formadores. ${ }^{3}$ Além de integrar a primeira diretoria, foi presidente da instituição por seis vezes, orador oficial, redator dos anais etc.

Um segundo grupo de atividades relevantes nessa fase inicial visou a transformação das antigas escolas médico-cirúrgicas do Rio de Janeiro e da Bahia nas faculdades de medicina. O processo envolveu conflitos de interesses entre a Junta do Protomedicato, as esferas legislativas e burocráticas do governo e a própria Sociedade de Medicina. Este tipo de atividade, de gestão de conflitos envolvendo o ensino médico e o exercício profissional, tornou-se um dos principais componentes da carreira de Jobim, como diretor de hospitais e da própria Faculdade de Medicina do Rio de Janeiro, que chefiou por trinta anos, de 1842 a 1872, com 
4 Santos Filho (1947; 1991) e Moacyr (1936, v. 1 , pp. $388-486 ; 1938$, v. 3, pp. 144-212) detalham as regulamentações jurídicas resultantes de confrontos entre representantes do ensino, do Legislativo e do Executivo no período imperial.

5 A principal atividade de quase todos os membros da academia, em qualquer período, foi a direção de burocracias públicas ou hospitalares, aliada à clínica e ao magistério, a funções ou postos militares e à política, variando a composição em cada caso. Ver Coradini (1994). o respaldo da congregação e do imperador. Nas palavras de seu biógrafo (idem, 1982, p. 96), as três principais esferas de atuação - a academia, a faculdade e o Parlamento - constituíam "três tribunas", que acionava conforme a natureza da questão (a luta contra os homeopatas, por exemplo).

Ao se criar a faculdade, como sucedera com a academia, na "falta de regulamentos ou de estatutos próprios adotaram-se os da Faculdade de Paris e, quando seus artigos e parágrafos não se ajustavam às peculiaridades exigidas pelas normas da Casa, baixava-se uma portaria ministerial, salvando-se a situação" (idem, 1980, pp. 259-60). ${ }^{4} \mathrm{O}$ apelo aos estatutos da escola de Paris não significa a adoção, de fato, da racionalidade, mesmo administrativa, que os gerou. Como lembra o biógrafo (idem, 1982, p. 92), "através da Câmara, o governo foi sempre pródigo em intromissões na vida administrativa da faculdade", através de "autorizações" e "ordens" que privilegiavam determinados alunos e de "avisos ministeriais (que) revolucionaram a ordem natural das coisas não só na faculdade do Rio, como inclusive, (n)a da Bahia". Em 1854, decorridos já 22 anos de ocupação do posto de diretor da faculdade, Jobim conseguiu que os governantes aprovassem seus estatutos. Isso, no entanto, não eliminou as interferências, pois o próprio diretor compunha o governo e, principalmente, porque a concepção de ensino subjacente amalgamava sua racionalidade com a do governo, como veremos adiante. Seja como for, a atividade 'administrativa' de Jobim, como a dos demais componentes da Academia de Medicina, ${ }^{5}$ ocupou a maior parte de sua carreira, tornou-se uma das principais fontes de seus títulos (junto com as atividades políticas) e permitiu-lhe legar o posto de diretor da faculdade ao genro, visconde de Sabóia, que iria se instalar nele à época da mudança do regime político.

Mas a trajetória de Jobim tem algo de particular em comparação à maioria dos contemporâneos da academia, especialmente a maior vinculação com a política (no sentido amplo) de sua carreira. Ela não se restringe às relações diretas com o imperador ou com os agentes das esferas centrais do poder político que, como visto, foram os responsáveis pela obtenção do título escolar. Esse tipo de vinculação é comum aos demais componentes da academia durante todo o período imperial. $O$ que distingue a trajetória de Jobim é o fato de haver conseguido converter tais relações em carreira propriamente política, na esfera legislativa e não apenas na gestão de burocracias públicas, civis ou militares, como a maior parte dos acadêmicos contemporâneos.

Basicamente, três pautas confluem para a acumulação de títulos e postos no caso desta carreira política. A primeira são as relações de reciprocidade ou de amizade com círculos do poder político, particularmente a família imperial. Em segundo lugar, a concepção 
6 Até a reforma de 1854 (Jobim já ocupava o posto há 12 anos), o diretor da faculdade era escolhido pelo imperador em lista tríplice apresentada pela congregação. Passou então a ser de livre escolha dele. Jobim foi nomeado para o Senado vitalício em 1856, aos 54 anos. Entre os postos de comando de burocracias públicas por nomeação do imperador destaco a direção do Hospício D. Pedro II. de medicina (como cultura geral ou política) e, por extensão, de exercício profissional, como demonstrarei adiante. Por fim, a reconversão desses recursos para a obtenção de postos de comando nas burocracias públicas e no Legislativo.

Os vínculos com a família imperial, que Jobim herdara do pai, começaram a se intensificar com as turbulências político-militares do Primeiro Império, que coincidiram com o retorno de Paris, já como médico diplomado. O imperador nomeou José Bonifácio tutor de seus filhos, e este, por sua vez, nomeou Jobim médico do Paço, médico, portanto, do futuro imperador d. Pedro II. Dessa ligação de amizade e confiança com ele, que se prolongou pelo resto de sua vida, resultaram vários títulos - o de conselheiro, por exemplo - e nomeações para diferentes postos de comando nas burocracias públicas, inclusive diretor da Faculdade de Medicina e de senador vitalício. ${ }^{6}$ A relação direta com a família imperial, importantíssimo trunfo social e político, que prosseguiu com a nomeação como tutor do futuro imperador, depois como médico da Câmara Imperial e, por fim, na aceitação como amigo, facilitou, também, a socialização nos "segredos palacianos", na manipulação de "configuração" (Elias, 1987) das relações de poder. Ou seja, como

"médico da Câmara Imperial desde os tempos de tutoria de José Bonifácio, tendo lugar à mesa de refeições ..., tudo indicava que Jobim se não participasse diretamente das decisões políticas, como o faria mais tarde, teria sido testemunha de muitos episódios desenrolados na intimidade das antecâmaras palacianas, permitindose propiciar o acesso do seu colega e companheiro da academia, Soares de Meirelles, à pessoa do jovem monarca" (idem, ibidem, p. 86).

A confiança da família imperial redundou não apenas em nomeações para postos administrativos, mas também em carreira política no Parlamento. Uma das primeiras missões decorrentes desta confiança foi a viagem de Jobim ao Reino das Duas Sicílias, como representante do imperador, para contornar uma intriga palaciana envolvendo as duas cortes. Ao regressar de Nápoles, Jobim foi designado médico da comitiva do imperador, que ia fazer a sua primeira visita às províncias do Sul. Na mesma ocasião, foi "nomeado para o conselho da coroa, recebendo, ainda em Porto Alegre, das mãos do monarca, o decreto imperial ... . Nessa ocasião, teria ainda o seu nome incluído na relação dos candidatos à Assembléia Legislativa sendo eleito deputado geral pela sua província" (idem, ibidem, p. 95). Depois foi 'reeleito' e, ao fim dos dois mandatos, seu nome foi incluído na lista tríplice para o Senado do Império, pela província do Espírito Santo. Por fim, d. Pedro IÍ nomeou-o para o Senado vitalício, aos 48 anos, sendo o 
7 Carvalho (1981, pp 96, 23-6) reconhece que, a influência familiar e o apoio dos amigos e líderes já estabelecidos era "presença constante em todos os passos da carreira". Aincla assim, um "diploma de estudos superiores, especialmente em direito, era condição quase sine qua non para os que pretendessen chegar até os postos mais altos". O autor não contempla os portadores de títulos de estudos superiores que não ocuparam posições de elite. Superestima o título na seleção de elites políticas numa estrutura social onde a profissão não era o principal fator de hierarquização. Por mais rato que fosse (em vista da preponderância dos analfabetos), o título influía apenas na chegada à elite, consagrando posição já assegurada por outros recursos. Sobre a reduzida importância da "competência técnica" nas posições sociais, mesmo nos Estados Uniclos, ver Collins (1979). primeiro dos sete senadores oriundos da Academia de Medicina (idem, ibidem, p. 117). Posteriormente, atribuiu sua eleição paradeputado geral a "amigos generosos, parentes e irmãos que gozam de estima e influência na minha província", e a eles dedicou seus 'Discursos', quando os publicou (idem, ibidem, p. 102).

Diversamente de outros trabalhos referentes à elite política do Império brasileiro, que enfatizam o título escolar como responsável por sua seleção e unificação, ${ }^{7}$ considero o valor real do título escolar como resultado da inserção de seu portador em determinados conjuntos de relações de reciprocidade. Ou seja, na ausência de uma estrutura que garanta a equivalência de títulos escolares e postos (Bourdieu e Boltanski, 1975), são as possibilidades de inserção de seu portador nas redes de relações personificadas que garantem o valor deste título escolar não apenas como atestação de determinado capital escolar, mas, principalmente, como elemento consagrador de uma posição social já ocupada de antemão com base no capital social (Bourdieu, 1980b). Nessas condições, o título escolar representa apenas um entre muitos outros títulos, e é na relação com estes que adquire valor.

Como já apontei, as relações sociais que deram origem aos principais títulos de Jobim convergem, ao longo de sua trajetória, para os agentes do poder político central, especialmente o imperador, numa espécie de "patrimonialismo em radial" (Oszlak, 1982). O ingresso nestas esferas dependeu, também, da posição de sua família, e a fundação desta, por sua vez, decorreu das relações com o imperador. Portanto, o grupo familiar constitui o nível mais imediato para o estabelecimento destas relações de reciprocidade, a condição inicial da acumulação de capital social. Por outro lado, existe a possibilidade de estas relações de reciprocidade e os respectivos títulos serem adquiridos por herança, através de gerações sucessivas.

Segundo Fernandes (1980, p. 258), apesar da insistência do imperador, Jobim nunca aceitou títulos de nobreza e preferiu

"ser chamado pelo apelido de família, só prezando com especial agrado o título de conselheiro. E tinha as suas razões. Ao contrário dos conselheiros integrantes do Conselho de Estado que indicavam o exercício de uma função pública, o título de conselheiro de Sua Majestade era uma graça honorífica, uma distinção com que d. Pedro II honrava uma personalidade quase sempre pertencente aos meios profissionais liberais e culturais. Era distribuído para premiar a capacidade intelectual e o mérito de homens de valor científico ou de pensamento, professores, magistrados, escritores ... assim como o baronato reconhecia de preferência o esforço do fazendeiro de café, agricultor bem-sucedido, do capitalista, do banqueiro, os grandes homens de negócio." 
O biógrafo aponta as razões que levaram Jobim a acolher tão honrosas distinções e, ao mesmo tempo, a recusar sistematicamente títulos de nobreza que o Império outorgava aos contemporâneos, "entre os quais figuram muitos dos seus colegas de medicina que se tornaram barões, marqueses e viscondes". Além da preferência por títulos mais 'honoríficos', pesou a aversão a títulos de nobreza que não se obtinham só por empenho ou amizade de ministros. "Custava também dinheiro, e não pouco, para o tempo." Mesmo assim, houve uma 'inflação' dessas regalias que, no final do Segundo Reinado, já eram distribuídas com liberalidade. Antes de receber o título de visconde, Salles Torres Homem (parente do próximo personagem) classificou a nobreza imperial de "aristocracia de chinelos, cujos brasões heráldicos o povo não podia contemplar sem rir-se deles" (idem, 1982, pp. 88-9).

A aversão de Jobim pelos atributos heráldicos não o impediu de utilizar seu prestígio para que fossem agraciados "o irmão Antônio, que foi barão de Cambaí, o primo Hilário Pereira Fontes, que seria barão de Viamão, e o genro, dr. Vicente Sabóia, todos com brasões de armas registradas em Cartório da Nobreza e Fidalguia do Império" (idem, 1980, p. 259). Porém, a sucessão abrangia não só títulos heráldicos, como também o prestígio, ou seja, o conjunto de relações de reciprocidade em que se baseavam as nomeações. É o caso do genro, que herdou, inclusive, a direção da Faculdade de Medicina.

$\mathrm{E}$, além dos títulos de nobreza, havia outras distinções e honrarias a serem acumuladas. Em 1842, foi agraciado pelo imperador com o hábito da Ordem de Cristo, "com a particular deferência de sustentar os varais do pálio imperial por ocasião da procissão do Senhor Morto". Mais tarde tornou-se comendador da mesma ordem. Alguns anos depois ser-lhe-ia conferido, por decreto imperial, o grau de oficial da Ordem da Rosa, a venera pelo fim da revolução Farroupilha e outros títulos como o de médico honorário do Hospital da Santa Casa. Jobim iria, inclusive, residir em Petrópolis, em terreno doado por $\mathrm{d}$. Pedró II (Fernandes, 1980, p. 265).

Como disse, a inexistência de um campo científico, ou mesmo escolar, faz com que o valor do título escolar resulte de sua inserção em redes de relações de reciprocidade, do respectivo capital social e, conseqüentemente, das vinculações com outros títulos. Nestas condições, as próprias regras escolares são recontextualizadas. Primeiro, porque as regulamentações e práticas escolares sofrem a influência das relações com a política (Moacyr, 1938, v. 3, pp. 179-80 e passim; Santos Filho, 1947) e o clientelismo; segundo, porque se redefinem os próprios critérios de realização profissional, apesar de sua origem importada. Em outras palavras, na medida em que inexiste um etbos e não se 
8 Por exemplo, ao apresentar a biografia de Jobim, em 1982, o presidente da Academia Nacional de Medicina destaca o fato de ter sido "pioneiro em vários empreendimentos culturais e a pluralidade de encargos que assumiu", como clínico, médico da Imperial Câmara, sanitarista e administrador. $O$ próprio biógrafo - ocupante da cadeira da qual Jobim era patrono encontra dificuldade para "harmonizar" tantas atividades, lembrando que Jobim foi criticado por ter sido um diretor "intermitente" da academia. "Todos, sem exceção", adverte, "acumularam, sem descloiro para o ensino, o exercício da diretoria com as obrigações de sua clientela particular, senão com outras funções públicas" (Fernandes, 1982, pp. 10, 139). objetivam as regras próprias do campo escolar e da organização profissional, os critérios que regem os investimentos profissionais e a avaliação de seus resultados são "multidimensionais", centrados na "pessoa moral".

Conforme um biógrafo e descendente, Sodré (1947, p. 150), a escolha de Jobim pela "medicina pública" seria "marcante na sua personalidade", já que era "a especialização preferida por todas as inteligências propensas à cultura geral. Ela excede às noções da medicina e invade os conhecimentos generalizados, sobretudo a sociologia e o direito." Segundo Fernandes (1982, p. 48), Jobim qualificava a "medicina política" como "aplicação contínua dos verdadeiros princípios da nossa arte ao entendimento da saúde pública e à administração da justiça", dividindo-a em duas partes, a medicina legal e a polícia médica ou higiene pública.

Observa-se, portanto, uma tendência a se definir medicina a partir daquilo que está mais próximo de conhecimentos próprios ao exercício do poder político ou da gestão de burocracias públicas. Nesse sentido, assemelha-se Jobim aos demais acadêmicos e, de certo modo, também às elites políticas brasileiras da época com titulação escolar superior, em sua maior parte oriunda de cursos de direito (Carvalho, 1981). Por outro lado, tal concepção de medicina e de exercício profissional é viável na medida em que seu exercício não requer o ethos do campo científico, visto que se trata de 'arte' e 'moral' tecnicamente garantidas (Bourdieu, 1984, p. 74).

A inexistência de um campo escolar e científico, com regras próprias, resulta na aplicação das regras vigentes em outras esferas da vida social às relações escolares e profissionais. Não as regras da sociedade de corte da França pré-revolucionária, pois, apesar de existir formalmente uma corte, estamos muito longe daquilo que foi explicitado por Elias (1987). Os princípios e as regras aplicados nas relações escolares e profissionais são principalmente os que se baseiam na reciprocidade, e que respaldam o exercício da política. Em conseqüência, por se tratar de relações personificadas, adquirem um caráter 'particularístico' e, amiúde, pessoalmente violento.

Isso se manifesta em todas as esferas de atuação, inclusive na Academia de Medicina, cuja dinâmica é perpassada pela lógica das relações políticas. Assim, por exemplo, com todos os acadêmicos e, particularmente, os que se formaram no exterior, a vinculação com determinada escola ou mestre consagrado é verticalizada, visto que se circunscreve à afiliação, sem comunicação 'interpares'. Ao mesmo tempo, no caso de Jobim e de outros, desenvolveram-se esforços no sentido de 'adaptar' algumas das idéias importadas, com vistas à aplicação local. Assim, na década de 1860 , Jobim procurou definir o que designou como 
9 Sobre a inexistência de uma medicina "brasileira", pelo menos até recentemente, ver Santos Filho (1991, pp. 313; 1967). Azevedo (s. d.) avalia as dificuldades e resultados dos esforços de introduzir $e$ institucionalizar a medicina $e$ outras áreas de conhecimento, e Schwartzman (1983) analisa historicamente os "modelos" institucionais postos em prática. "hipoemia intertropical" com base nas idéias do 'essencialismo'. Um pesquisador alemão, Otto Wücherer, publicou no mesmo período uma série de resultados em autópsias negando a tese de hipoemia intertropical, e apresentou-os na Academia Imperial de Medicina.

"Fiel à doutrina essencialista, Jobim se sentiu no dever de comparecer à academia para reafirmar ... as razões que o levaram a apresentar ao mundo médico concepção de identidade clínica por ele denominada de hipoemia intertropical como doença vinculada às condições climáticas. $\mathrm{E}$ de tal forma se houve na sua argumentação que, após animado debate, posta a matéria em votação, obteve os sufrágios unânimes dos presentes solidários, mais com a sua autoridade do que mesmo convencidos da legitimidade de sua tese" (Fernandes, 1980, p. 257).

Nessa ocasião, encontrava-se entre estes "o já celebrado professor Torres Homem, futuro barão do mesmo nome, que permaneceria adepto da doutrina ... por ele aplicada à interpretação das febres do Rio de Janeiro" (idem, 1982, p. 67).

Trata-se de um esforço de "elaboração de uma doutrina mesológica de conotação nacional" (idem, ibidem, p. 266), ${ }^{9}$ mas não é apenas o nacional que tem conotação política. A própria autoridade de fundador e presidente da academia é política e faz com que as relações e práticas sociais sejam aí politizadas, sejam, portanto, relações de reciprocidade e particularizadas.

A dinâmica desta polêmica entre 'doutrinas' (que repercute, inclusive, na trajetória de Torres Homem) constitui um dos melhores exemplos da subordinação da lógica acadêmica à política e às estruturas de poder respaldadas em relações de reciprocidade. A principal conseqüência são posições tomadas com base nas afiliações pessoais e, portanto, impossibilidade de mudanças de posição sem rupturas de vínculos pessoais. Desde o aparecimento da febre amarela, diz Fernandes, durante mais de meio século, a academia debateu-a em todos os seus aspectos, assumindo "feição altamente polêmica senão violenta" o debate entre os contagistas, liderados por Cruz Jobim, e os não-contagistas, que contavam com o apoio de Torres Homem. A discussão "se arrastava sem nada inovar ... . Só com o advento da era pasteuriana ... é que a academia mudaria o rumo das suas discussões, em busca do agente causador da febre amarela." Os confrontos que se seguiram à chegada dos estudos de Pasteur, no entanto, resultaram em lutas pessoais pela 'primazia' das supostas 'descobertas' possibilitadas pela aplicação local de sua teoria, numa sucessão de conflitos personificados, negação de supostas evidências e da busca de legitimidade nos centros europeus (idem, ibidem, pp. 111-3). 
O caráter personificado das lutas e conflitos manifesta-se de outras formas e em outras esferas, como a da administração escolar. Aí transcorreram os conflitos mais destacados de Jobim, como o que travou com um outro professor da Faculdade de Medicina, Nunes Garcia, classificado por ele como o "negro mais desavergonhado da escola", na polêmica que mantiveram nos 'A Pedidos' do Jornal do Commercio" (idem, 1980, p. 263). O episódio é relevante para a apreensão das concepções subjacentes por se tratar de um conflito de ordem simultaneamente pessoal, didática, administrativa e política. Foi deflagrado pelo preenchimento de uma vaga de anatomia que Nunes Garcia, professor substituto de cirurgia, pleiteava. Na polêmica que se seguiu, sobre as interpretações dos estatutos da Faculdade de Paris, chegou-se à conclusão de que isso era administrativamente possível. "Acontece que os interesses políticos ... mudariam o curso dos acontecimentos através da vontade manifestada por Bernardo de Vasconcellos, então ocupando a pasta do Império, em favor de seu conterrâneo Domingos ... Americano que acabara de concluir o curso médico." A direção da faculdade adiou o concurso para "contemporizar com a pretensão ministerial", mas o novo ocupante da pasta do Império resolveu nomear Nunes Garcia catedrático de anatomia, contra as preferências do antecessor, "gerando grave crise no Gabinete". Instado a servir de mediador entre a faculdade e o ministério, Jobim convenceu-se de que, caso Nunes Garcia fosse nomeado, "a posição do conselheiro Galvão no Gabinete ficaria insustentável". A solução então proposta foi a realização de novo concurso, mas Nunes Garcia, "esse petulante professor de anatomia", insurgiu-se contra o poderoso conselheiro e senador, iniciando-se um longo conflito pessoal, inclusive através da imprensa comercial (idem, ibidem, pp. 134-237).

Esta concepção, que subordina e amalgama o ensino com a administração, e esta com a política, fica ainda mais explícita nos esforços de Jobim pela reforma do ensino médico, conseguida na gestão de seu genro, Sabóia, como diretor da faculdade, no fim do período imperial. Os conflitos nas relações entre ensino e política passaram a ser uma constante nas manifestações de membros da academia no período posterior (Coradini, 1994), porém nunca se conseguiu superar este amálgama através da objetivação social dos modelos administrativos importados. Mas seja em relação à totalidade dos componentes da academia, seja no caso específico de Jobim, isso pode ser interpretado como manifestação do caráter híbrido, ambivalente, que a importação de modelos ocidentais gera (Badie e Hermet, 1990). Jobim, por exemplo, em discurso como senador, proclamava a necessidade de concursos para o recrutamento de professores, tendo em vista 
${ }^{10}$ A fonte mais completa é a biografia elaborada por um médico, neto de um "discípulo" de Torres Homem (SattaminiDuarte, 1957). Perfil do autor acha-se em Revista do IHGB, v. 329 de 1980 (pp. 151-3). Como Jobim é patrono da Academia de Medicina (cadeira $\mathrm{n}^{\circ} 8$ ), é contemplado em perfis biográficos apresentados na instituição e em publicações de consagração coletiva, como Lacaz (1963), editado pelo Laboratório Pfizer, e Tribuna Médica (mar. 1967, p. 21). as "nossas circunstâncias peculiares e políticas", em que "as letras e as ciências" não estariam "tão adiantadas como em quase toda a Europa". E conclamava o governo a "sujeitar-se francamente ao resultado do concurso, aceitando o primeiro apresentado, e não obrigando o júri apresentar três para ele escolher um" (Fernandes, 1982, pp. 150-1). Portanto, nesse caso, tratava-se de destacar a lógica escolar ou, pelo menos, sua administração, em detrimento do governo ou da política, buscando legitimidade, inclusive, nas regras de funcionamento deste tipo de instituição nos países europeus, em particular a França.

Por outro lado, ao justificar a necessidade de se criarem novos cursos, como direito e engenharia no Rio de Janeiro, e ao se opor à Faculdade de Direito de São Paulo, reiterava o amálgama entre ensino e política. Opunha-se, principalmente, nesse caso, ao estatuto das faculdades de direito de São Paulo e Recife, que "deixou ao talante da administração desses estabelecimentos determinar não só os métodos de ensino como a escolha dos compêndios adotados para as respectivas cadeiras". A oposição à 'libertinagem' escolar e a ênfase na necessidade de regulamentação governamental incluía a própria definição de política enquanto representação: por "estarem fora das vistas diretas do governo há faculdades que admitem compêndios que defendem doutrinas as mais dissolutas, como acontece em São Paulo, onde o professor de direito público chega ao extremo de recomendar a leitura do Contrato social de ... Rousseau. Ninguém de boa fé ou de boa formação jurídica admitiria tamanho despautério." É evidente que na França, onde iam buscar legitimidade as posições tomadas aqui, idéias como as de Rousseau já se haviam difundido e sedimentado. Porém, a importação de idéias envolve estratégias de seleção. No caso, a justificativa é que lá não havia "dissolução de costumes" nem "libertinagem": na "Universidade de Paris ... os professores eram acatados e respeitados" (idem, ibidem, pp. 170-1).

Como já foi mencionado, o principal herdeiro de Jobim, tanto no âmbito familiar (genro) como nos planos político-institucional e profissional (sucessor na direção da faculdade) foi Vicente Candido Figueira de Sabóia (barão de Sabóia). Porém, a existência de informações mais abundantes permite apreender melhor esta sucessão através da trajetória de João Vicente Torres Homem (barão de Torres Homem). ${ }^{10}$

As condições sociais de realização profissional de Torres Homem (e, por extensão, do conjunto dos componentes da academia de sua geração) são muito semelhantes às de Jobim. Os principais recursos para ascender à elite continuaram a ser as relações personificadas com componentes da elite profissional, com agentes do poder político (especialmente o imperador) $e$ 
11 Ver Santos Filho (1947, 1991) e Coradini (1994). Um dos temas da reforma do ensino médico era a pouca procura pelos cursos. Segundo Fernandes (1982, p. 144), antes de 1854 os graduados no Rio e na Bahia perfaziam, em média, quarenta. "Tomando-se como referência o ... ano de 1862 , esse número, também em termos médios, decresceu para seis." Daí as propostas de mudança de currículo e de criação de novos cursos nas capitais regionais. com ocupantes de postos nas burocracias públicas. Por outro lado, a trajetória profissional de Torres Homem é marcada, também, pela importação de novos avanços técnico-científicos da França e de outros países da Europa com profundas implicações para a medicina (Léonard, 1981; Foucault, 1987). Além disso, Torres Homem distingue-se dos contemporâneos que compõem a elite médica brasileira por investir mais na profissão, especificamente, em detrimento da política ou de postos de comando administrativo. Por fim, como sua trajetória coincide com o final do período imperial, é possível apreender o significado que as mudanças institucionais provocadas pelo advento do período republicano tiveram para a profissão médica e a reprodução de sua elite.

$O$ ingresso de João Vicente Torres Homem no curso de medicina e, mais especificamente, os critérios utilizados nesta escolha constituem um dos melhores indicadores das dificuldades na adoção de uma profissão em uma estrutura social que não a tomava como princípio preponderante de hierarquização. Tratavase de obter um título escolar ao qual correspondia uma carreira profissional, cuja estrutura organizacional havia passado por uma série de mudanças na fonte principal de importação, a França, mas cuja adoção se defrontava com condições sociais e culturais locais adversas.

Torres Homem nasceu em 1837. Ao ingressar no curso de medicina, a imagem social deste, no Brasil, ainda era marcada por forte presença dos cirurgiões e sua utilização em atividades militares (sem falar na ingerência dos agentes da Igreja Católica). ${ }^{11}$ Por outro lado, como se tratava de alguém de origem social elevada, numa sociedade social e culturalmente marcada pelo escravismo e o conseqüente desprezo pelo trabalho manual, sem condições, portanto, de abrigar ideologias meritocráticas, como a da elite médica francesa contemporânea (Weisz, 1988a, 1988b), a decisão de cursar medicina defrontava-se com a imagem de profissão manual, pouco 'nobre'.

O obstáculo foi superado porque o pai fazia parte da elite médica, a exemplo de outros membros do grupo familiar, apesar de pertencer à elite política. Diversamente de outros componentes da elite médica da mesma geração (e das mais diversas regiões), Torres Homem era da própria capital do Império, o que "marcou, em toda a sua vida, a atitude urbana que ele sempre teve, no meio de tanta gente de raízes rurais". Seu pai, natural de Campos, foi "deputado pela sua terra; era pessoa de excelente situação social, embora se diga ter tido origem modesta. ... Não tanto que o impedisse de estudar em Paris, onde haveria de bacharelar-se em ciências e letras. Ainda nessa cidade, estudou medicina $\mathrm{e}$ doutorou-se" (Sattamini-Duarte, 1957, pp. 21-2). Foi "médico do Paço" (idem, ibidem, p. 41), professor e diretor interino da 
Faculdade de Medicina, chefe de enfermaria no hospital militar da Corte e presidente da Academia Imperial de Medicina. Tinha um primo, médico também, "formado pela antiga Academia Médico-Cirúrgica do Rio de Janeiro, advogado pela Faculdade de Direito de Paris" (idem, ibidem, p. 27). Tornou-se político e ocupou postos nas burocracias públicas, como a direção do Tesouro e a direção do Ministério da Fazenda.

Após concluir os primeiros estudos em colégios particulares, Torres Homem ingressou na Faculdade de Medicina do Rio de Janeiro. A escolha foi influenciada pela situação do pai, que não tinha "ojeriza" pela medicina e "preconceito muito maior" contra o cirurgião, carreira considerada "pouco nobre", não compatível com os "homens bons" (idem, ibidem, p. 28).

Apesar de não ter feito carreira política, desde o início do curso, sua vida escolar foi condicionada pelas relações com o pai, os amigos dele e a política (em sentido amplo). Foi aluno do próprio pai e de outros membros da Academia Nacional de Medicina, como Paula Cândido, "quase sempre deputado", cujas aulas "devem ter sido dadas por algum substituto"; José M. N. Garcia, filho do padre José Maurício, que "passou a vida brigando com o conselheiro Jobim" etc. No final do curso, passou a ser "interno-residente" no Hospital Militar da Corte, onde "seu pai tinha sido primeiro médico, com as honras de cirurgião-mor de divisão, até morrer e, ocasionalmente, diretor. Fizera boas amizades, naturalmente. Talvez por isso, ou por mera coincidência, aí trabalhou, muitos anos, como almoxarife, o cunhado Pereira Codeço." Dentre os mestres e médicos que conheceu nesse hospital, quem "mais o impressionou foi o professor de clínica médica ... Manuel Valadão Pimentel, barão de Petrópolis", substituído na direção da faculdade por Jobim, que "era médico do imperador, desde menino e tinha grande influência". Sob a influência de Valadão e do próprio pai, optou pela clínica, em detrimento da cirurgia. Formou-se em 1858, mesmo ano em que morreu o pai. Assim, terminou aí a interferência direta deste, mas não a interferência indireta (idem, ibidem, pp. 31, 32-3).

Toda a carreira de Torres Homem teve como base a ampliação da rede de amigos (e amigos dos amigos) de seu pai, estratégia favorecida pela estreiteza numérica e centralização geográfica da elite médica e política. Mas diversamente de quase todos os contemporâneos da Academia de Medicina, que passaram a maior parte do tempo em postos político-administrativos, Torres Homem teve na clínica e no magistério as principais esferas de atividades (Coradini, 1994).

Logo após a formatura, no "consultório que fora do pai, iniciou a clínica particular", ao mesmo tempo que passou a atuar na Academia de Medicina, lutando aí "contra os consultórios em farmácia". 
12 Os trabalhos mais importantes de Torres Homem são as Liçôes de clinica médica, em três volumes, além de outras publicações sobre febre amarela $\mathrm{e}$ artigos em jornais médicos. Foi um dos acadêmicos que mais publicou, até aquela época. E, ao contrário de boa parte de seus pares, foi o que se dedicou menos a temas "externos" à medicina (literatura, polêmicas político-militares etc.). Informações suplementares sobre as publicações médicas do período constam em Santos Filho (1991, p. 45; 1967, p. 477) e Coradini (op. cit.).

${ }^{13}$ Sobre os conflitos que este "filhotismo" suscitou, envolvendo, inclusive, agentes do Legislativo, ver Moacyr (1938, v. 3, pp. 179-80) e Santos Filho $(1967$, p. 229 e passim). Listagem apologética das vinculaçôes de parentesco entre esses membros da academia encontra-se em Pedro Nava, item seguinte.
Em seguida, realizou concurso para o cargo de opositor ("de muita modesta hierarquia e absolutamente dependente do catedrático") na Faculdade de Medicina, e se tornou médico adjunto da Santa Casa, onde "trabalhava com Valadão, de quem talvez recebesse as sobras da clínica". Em 1862, em conjunto com outros, fundou a Gazeta Médica do Rio de Janeiro, uma das poucas publicações especializadas na época, e começou a publicar seus primeiros trabalhos. ${ }^{12}$

No ano seguinte, "ouviu, como verdadeiro presente de Natal, do presidente da casa, barão de São Félix, que o imperador aprovara sua nomeação para membro titular da Academia Imperial de Medicina". Foi "introduzido no recinto" por Sabóia e Nicolau Moreira, quando os acadêmicos ainda utilizavam a instituição como "cenáculo literário", sendo que o "próprio imperador, sempre presente às sessões solenes, gostava de literatura".

Pouco mais tarde, em 1865, com a abertura de uma vaga na Faculdade de Medicina, Torres Homem apresentou-se como um dos concorrentes para a cadeira de higiene e história da medicina, mas não conseguiu ser classificado; "durante breve período, substitui, interinamente, o barão de Petrópolis na cátedra de clínica interna, que vai finalmente a concurso". Nele fica mais evidente o confronto entre os critérios baseados no capital social e as regras jurídicas que chegaram a ser suspensas. No concurso inscreveram-se quatro concorrentes, inclusive Torres Homem. "Gente toda de muito peso médico e político. O mais provável era Silva, 'homem que nasceu médico, teve irmãos médicos e era filbo de notável professor da faculdade, mas de diminuta resistência física."13 Desse modo, Torres Homem "não obteve o primeiro lugar, que coube realmente a José Joaquim da Silva; que 'não podia arrostar as fadigas cotidianas do magistério, nem dedicarse tão afincadamente ao estudo'. ... Mas sobreviveu quatorze anos a João Vicente (Torres Homem), contrariando assim os prognósticos." Frente à situação, e não "obstante o resultado do concurso, foi nomeado para a vaga", na mesma época em que casou, aos 28 anos (Sattamini-Duarte, 1957, pp. 52, 56-7, 65, 67).

Como disse, comparativamente aos demais acadêmicos que compunham a elite médica, a carreira de Torres Homem caracterizou-se por ser menos vinculada à política, no sentido formal. Ou, como enfatiza seu principal biógrafo, "foi sempre o oposto de certos doutores ... mais ocupados com a política e com a guerra". Contudo, além de se envolver em confrontos concernentes a 'doutrinas' médicas, sempre tomou posições em relação às políticas de saúde ou outras. Iniciou uma das primeiras e principais atuações políticas dessa natureza em 1874, quando, "juntamente com o barão do Lavradio e o doutor Souza Costa, foi incumbido de apresentar um projeto de melhoramento sanitário 
da cidade" (idem, ibidem, pp. 83, 93). Mais tarde foi relator de uma comissão nomeada pelo governo para avaliar a pretensão de que a homeopatia fosse ensinada na faculdade. Tomou posição absolutamente contrária à questão.

Seja como for, apesar de ter morrido relativamente jovem, aos cinqüenta anos (devido a doença tida como hereditária), Torres Homem é considerado um dos médicos mais bem realizados profissional e socialmente. Para alguns, era "o maior médico do Brasil, de todos os tempos" (Tribuna Médica, mar. 1967, p. 21). Em geral, essa realização é atribuída às publicações, ao número de discípulos que deixou coma professor e à atividade como clínico. No que tange à realização social, enfatizam-se suas vinculações com a família imperial e a proeminência no seio da elite médica.

Como médico e professor, é considerado sucessor do barão de Petrópolis, o único que fez escola, deixando "os melhores e mais numerosos documentos nas muitas obras que publicou". Boa parte dos discípulos ingressou posteriormente na Academia de Medicina - Francisco de Castro, Miguel Couto, entre outros (Sattamini-Duarte, 1957, p. 141). Mas, ao contrário de muitos acadêmicos contemporâneos, que neste período intensificaram a endo-reprodução através da formação de estirpes ou clãs de médicos do mesmo grupo familiar, Torres Homem legou a profissão apenas aos discípulos. Divergia também dos demais membros da academia, cujas 'qualidades' geralmente destacadas eram "amizade" e "bondade" (Coradini, 1994), pois não "chegou ... a ser popular ... sua maior projeção se fez sempre no meio da própria classe". Isso não implica que não utilizasse sua "influência" ou "prestígio" a serviço dos "discípulos". Por exemplo: quando "o mais moço dos assistentes, Miguel Couto, desesperançado de conseguir clínica na Corte, procura o chefe e pede-lhe que o ajude", recebe cartas de recomendação para dois marqueses.

Em termos econômicos, tinha "fama de apegado ao dinheiro". Morreu cedo, mas teve tempo de se tornar abastado (SattaminiDuarte, 1957, pp. 150, 131, 122). Por fim, ainda como realização social, mesmo "não sendo médico da câmara imperial", foi convidado para tratar do imperador, que pouco depois concedeulhe o título de "barão de Torres Homem, com grandeza", pouco antes de sua morte, em 1887 (Torres Homem, 1964, pp. 381406; Santos Filho, 1967, p. 488).

Como vimos, Torres Homem é considerado "o maior clínico do Rio de Janeiro no século XIX" (Gazeta Médica, 1862-64). Além da quantidade de discípulos e do sucesso clínico, a proeminência ou 'notabilidade' é atribuída às atividades de ensino e às publicações. Dentre estas, destacam-se os três volumes de Lições de clínica medica, publicados entre 1867 e 1887, e a criação 
11 Isso se manifestava, inclusive, na linguagem e no ritual escolar. Conforme um dos biógrafos, "nossa medicina era como um reflexo da medicina francesa e os professores procuravam transmitir os assuntos de suas aulas em esmerado estilo literário, o que por vêses (sic) prejudicava o rigor científico da exposição". Já os trabalhos de Torres Homem "eram escritos em linguagem precisa, tanto pelos conceitos como pelo estilo literário" (Olinto, s.n.t., p. 2, 5, Arquivos da Academia Nacional de Medicina, pasta $\mathrm{n}^{\circ}$ 96). do periódico Gazeta Médica, em colaboração com Vicente C. F. de Sabóia (visconde de Sabóia), genro e sucessor de Jobim. Nestas publicações "há de tudo, desde higiene até pediatria", visto que foram escritas por um médico "geral, à moda antiga discorrendo sobre toda patologia" (Tribuna Médica, mar. 1967, p. 21).

Diversamente de Jobim, de seu próprio pai e de outros componentes da Academia de Medicina, que se formaram na França ou fizeram viagens de estudos para lá e para outros centros europeus, Torres Homem nunca saiu de sua cidade, devido à falta de saúde. Conseqüentemente, só recebeu orientação profissional "de seus próprios patrícios e, desses, a de Valadão Pimentel, com quem se iniciara". À época em que transcorreu sua carreira, um dos principais confrontos na medicina girava em torno da interpretação das febres. Numa publicação de 1869 , em posição próxima à de Jobim e contrária à de Otto Wücherer, negou "que fossem os vermes causa da hipoemia intertropical (anemia hoje reconhecidamente de origem parasitária)" (SattaminiDuarte, 1957, pp. 143, 85). Depois, com base em observações clínicas, contestou a idéia corrente do contágio como forma de transmissão da febre amarela. Mas a principal polêmica em que se envolveu foi o resultado da difusão dos trabalhos de Pasteur.

Apesar da importância atribuída por Torres Homem à observação clínica e às autópsias (diversamente da maior parte dos médicos de então, que tinham concepção mais livresca de medicina), ${ }_{11}^{11}$ isso não foi suficiente para superar suas resistências às descobertas de Pasteur. Porém, o que é elucidativo do conflito entre a racionalidade institucional decorrente das condições brasileiras e a racionalidade acadêmica não é tanto o fato em si; são as formas e a dinâmica das lutas em torno destas descobertas. Torres Homem, que "até o fim teve inimigos" e, fiel a seus princípios, "foi ao fim descrente das teorias e descobertas de Pasteur", teve envolvimento muito direto com as polêmicas então suscitadas. Acompanhava de perto os trabalhos, "naturalmente prevenido contra a microbiologia, que nestes últimos anos tem querido avassalar toda a patologia celular" (idem, ibidem, pp. $150,128)$.

Nesse período, um professor da Faculdade de Medicina, "como Pasteur, químico e cada vez mais interessado na microbiologia", supôs ter 'descoberto' um novo micróbio. Para Torres Homem, em caso de comprovação, o mesmo teria direito à "gratidão nacional" como "benemérito". Mas "a oposição a Freire (autor da descoberta) passou a ser sistemática" e mesmo "aqueles que com ele iniciaram os trabalhos 'e fruíram a princípio e com orgulho as migalhas da sua glória' passaram a atacá-lo violentamente. Tal a celeuma levantada que Freire acabou por abandonar a Academia de Medicina, em 1885, atacado por todos, velada ou abertamente." 
15 João B. cle Lacerda (1846-1915), os irmãos Álvaro (1882-1952) e Miguel Osório de Almeida (1890-1953) são, entre todos os acadêmicos examinados, os que maiores investimentos fizeram por uma carreira de "pesquisador", apesar de terem também ocupado postos de comando administrativo. Natural de Campos (RJ), Lacerda fez deslocamento mais comum na fase posterior: depois de formado, retornou à terra natal, para clinicar, e, em seguida, reaproveitando relaçôes estabelecidas, voltou ao Rio de Janeiro para desempenhar atividades políticas, administrativas e/ou acadêmicas. Nesta e em outras trajetórias verifica-se a tensão entre a carreira de pesquisador e as relações personificadas com o imperador e outros membros do poder político. Defensor da pesquisa como carreira, Lacerda passou a maior parte do tempo no Museu Nacional. Mirando-se no exemplo de Pasteur, publicou mais de sessenta títulos. (Lacaz, 1963, pp. 3, 61; Jornal do Commercio, 12.7.1946; Arquivos da Academia Nacional de Medicina, pasta 138).

${ }^{16}$ Apesar de ser cirurgião, "crescente foi o entusiasmo do barão pelos trabalhadores de laboratório, decorrência de seus estudos e observações no Instituto Pasteur" (Tribuna Médica, mar. 1966, p. 17). $\mathrm{O}$ "eminente monarquista" investiu o prestígio decorrente da amizade com o imperador na criação do Instituto Vacínico, que se transformou depois no instituto chefiado por Oswaldo Cruz.
No ano anterior, numa de suas publicações, Torres Homem, "com toda a autoridade de mestre já célebre, procurava opor barreiras às chamadas doutrinas microbianas", enquanto oficialmente "o Brasil tomava conhecimento dos trabalhos de Pasteur", sendo-lhe, inclusive, concedida a "grã-cruz da Ordem da Rosa, que lhe mandara Pedro Segundo" (idem, ibidem, pp. 128, 129, 121). Nestas polêmicas, um antigo "interno" e "discípulo" de Törres Homem (e "precursor de Oswaldo Cruz e Carlos Chagas"), João Batista de Lacerda, ${ }^{15}$ "queixou-se, em sessão da Academia, de 'expressões pouco dignas' com que o atacara. E começou a fazer-lhe campanha aberta. Para, mais tarde, cair no mesmo engano, quando proclamou o isolamento de um fungo."

Posteriormente, as descobertas de Pasteur provocaram uma série de reconversões. O caso exemplar é o de Pedro A. de C. Franco (barão de Pedro Afonso, 1845-1920).$^{16}$ Mas independentemente dos resultados das posições em pauta e das descobertas científicas, seja de Pasteur ou de qualquer outro, o que cabe ressaltar são os usos sociais das relações com o campo científico que as lutas evidenciavam. Caracterizam-se esses usos, em primeiro lugar, por uma relação de apropriação exclusivamente prática dos resultados prováveis dos avanços científicos, em termos de glórias, benemerência etc. A racionalidade acadêmica fica assim excluída. Conseqüentemente, não são os esforços e nem um determinado conjunto de conhecimentos que legitimam e hierarquizam as posições. A concorrência tem como critério principal a adesão a posições que ofereçam maiores chances de sucesso enquanto produto de utilização prática, independentemente de sua inserção na racionalidade acadêmica. Em segundo lugar, como as relações não se pautam pela racionalidade acadêmica e não guardam autonomia frente às vinculações personificadas e políticas, os confrontos tendem a ser carismáticos e até violentos, na medida em que há envolvimento da "pessoa total" (Bourdieu, 1981, p. 19).

Torres Homem não viveu a mudança de regime, ao contrário de Sabóia, seu contemporâneo, sucessor de Jobim. Sabóia ocupava, então, a direção da Faculdade de Medicina. Há, pois, um interregno entre o fim da carreira de Torres Homem e o início da de Pedro da Silva Nava, que tomo como representativa das trajetórias da elite médica do século XX.

Entretanto, as mudanças mais significativas nas condições sociais em que elas se realizam não estão vinculadas à mudança de regime, circunscrita à esfera político-administrativa. Assim, apesar das vinculações personificadas com figuras das esferas da dominação política e, especialmente, com o imperador, a mudança de regime político teve efeitos mais ou menos superficiais no recrutamento dessa elite profissional. O efeito mais importante 
17 Ao contrário do que aconteceu na França (Léonard, 1981). Sobre as mudanças na trajetória de um clã de médicos monarquistas - os Fonseca (pai, irmãos, filhos) - ver $O$ Ilospital (dez. 1968, pp. 2.221-2). Quanto aos efeitos da mudança de regime nos rituais da Faculdade de Medicina e às posições tomadas por membros da academia, ver Lacaz (1963, p. 8) e Tribuna Médica (mar. 1966, p. 17). Sobre os médicos que professaram o republicanismo no Império, ver Santos Filho (1984, p. 181).

18 No curriculo de Nava constam 196 títulos, sendo 22 do magistério, além de homenagens,(Arquivos ANM, pasta 418). Boa parte dos 52 trabalhos publicados é dedicada à sua especialidade, a reumatologia, ou senão à medicina do trabalho, medicina e humanismo, história da medicina. As memórias, principal fonte para o presente artigo, consagraram-no na literatura. Utilizo também os Arquivos da Academia Nacional de Medicina, homenagens (Salles e Gama, 1987) e especialistas em literatura (Arrigucci Jr., 1987; Aguiar, 1994). foi a substituição do imperador por outros agentes e instâncias no processo de estabelecimento das mencionadas relações de reciprocidade e, conseqüentemente, a substituição de alguns ocupantes de postos indicados pelo monarca. Apesar da interferência nas carreiras de alguns dos personagens mais identificados com o regime anterior, no conjunto da Academia de Medicina, isso teve pouca relevância. ${ }^{17}$

As principais diferenças que se observam na carreira de Pedro Nava, em comparação com as anteriores, dever-se-iam não tanto à mudança de regime, mas às novas condições sociais de realização profissional, sobretudo a maior extensão e diversidade da estrutura de oferta de serviços médicos e sua imbricação com as políticas governamentais e com a clínica. Pesou, também, a expansão e descentralização geográfica da oferta de ensino médico, se bem que no período de sua formação, na década de 1920, esta ainda fosșe incipiente.

Quanto ao capital social e suas vinculações com os títulos escolares, as relações tornam-se mais complexas e diversificadas, mais sofisticadas, inclusive. Porém, ao contrário do que se poderia supor, sua importância é ainda mais decisiva para a ascensão à elite médica. A principal diferença, e a mais geral, em relação às condições anteriores, é que as redes nas quais se realiza esse capital social já não são centralizadas no poder central ou na figura do imperador; formam um conjunto mais vasto de redes que perpassam as esferas educacionais, profissionais e de consagração (como a Academia de Medicina). Em outras palavras, a estrutura de mediação torna-se menos radial e mais multicentrada. $O$ parentesco, a amizade, a patronagem profissional e suas vinculações com a política continuam a ser as principais bases sociais (Boissevain, 1966) das relações de reciprocidade, mas aumenta muito a amplitude e diversidade de sua realização. Por fim, amplia-se, também, enormemente, a quantidade de títulos (escolares, profissionais e honoríficos) devido aos avanços técnicos, à complexificação da profissão e ao fato de a carreira envolver um conjunto mais diversificado de esferas de atividades e maior consagração cultural através da literatura. ${ }^{18}$

Como já foi referido, a maior parte do material utilizado para a análise da trajetória de Pedro Nava provém de suas memórias. Com caráter de confissão e depoimento, explicitam, inclusive, seus próprios objetivos, bem como o conjunto de concepções que o autor subscreve. Nestas memórias, ao mesmo tempo em que narra fatos relativos à sua trajetória e à de seu grupo familiar, expõe as interpretações e concepções subjacentes. As relações entre o capital social e a ascensão à posição de elite, que nos interessam mais de perto, são apresentadas de modo direto, tal como em outras publicações sobre o autor (por exemplo, a home- 
19 Em biografias de consagração geradas num contexto cultural onde predominam ideologias meritocráticas, as relações vinculadas ao capital social são apresentadas de modo diferente. Saint Martin (1980, p. 5), por exemplo, é obrigado a analisar as propriedades e "relações dissimuladas" neste tipo de biografia. No caso em pauta, inexistindo ideologias meritocráticas, sendo culturalmente legítimas as relações de reciprocidade, estas são apresentadas de modo direto e solene. nagem da Faculdade de Medicina da Universidade Federal de Minas Gerais, de 1987). ${ }^{19}$

Para Pedro Nava, tanto suas memórias como os discursos, como orador oficial da Academia de Medicina, têm função explícita de construção de imagem e consagração social dos grupos familiar e profissional. Constituem, inclusive, um vasto painel de genealogias e suas vinculações com os círculos sociais mais amplos, tais como os de amigos, colegas escolares ou profissionais.

As memórias, especificamente, têm como um de seus objetivos transmitir "aos filhos, aos sobrinhos, aos netos, a lembrança dos pequenos fatos que tecem a vida de cada indivíduo e do grupo com que ele estabelece contatos, correlações, aproximações, antagonismos, afeições, repulsas e ódios", sendo "o elemento básico na construção da tradição familiar" (Nava, 1973, p. 17). Ou seja, a tradição constrói-se pela transmissão da série de vinculações e imagens sociais que os componentes do grupo familiar partilham com outros círculos sociais.

Mais especificamente, um dos objetivos da genealogia é a procura das "razões de valores físicos e de categorias morais e do valor-saúde", tendo em vista as alianças matrimoniais e a formação da "unidade cultural" do país, que não significa "unidade racial", mas supõe a predominância dos "lusitanos". Um segundo objetivo da genealogia são as heranças de patrimônios econômicos. $O$ "gosto pelas genealogias pode, ainda, provir do orgulho do encadeamento de gerações dadas a um mister, a uma profissão, e estabelecem-se assim árvores genealógicas de magistrados, notários, médicos, militares ... . Na medicina, a história de nossas faculdades se confunde um pouco com a de certas famílias de médicos. Basta citar as 'capitanias hereditárias' de nossa federal" (idem, ibidem, pp. 179-80, 183).

A sua família é "como as outras, só que antiga", contando com "constituintes, deputados, senadores, ministros, doutores, coronelões, letrados, analfabetos, 21 titulares de Pedro I e Pedro II, um governador de Minas ...; um presidente da República e um contraventor de jogo de bicho" (Nava, 1973, p. 187). Apesar de ter sido médico, o pai de Pedro Nava, por ter morrido novo, aos 35 anos, e não ter feito carreira no Rio de Janeiro, não chegou a formar um clã como era a tendência generalizada entre os componentes da academia no período, mais até do que no anterior (Coradini, 1994). Como resultado, toda a sua trajetória constitui um esforço visando a mediação entre o grupo familiar (ou o clã em sua própria linguagem) e a profissão, acionando-se vinculações com componentes do próprio grupo ou recorrendo a eles para ter acesso a outras esferas sociais.

Sinteticamente, o grupo familiar de Pedro Nava, no Brasil, tem suas origens no Norte. Do lado paterno, iniciou-se com seu bisavô 
(um imigrante italiano) no Maranhão. $\mathrm{O}$ avô paterno nasceu em São Luís e, apesar de não ser letrado, "possuía uma instrução bem acima da média". Tendo se deslocado para Fortaleza, onde se estabeleceu como comerciante, "foi aceito para casamento numa família antiga, bem apresentada na província e politicamente atuante nesta como noutras do Norte e Nordeste do Império". A avó, "Ana Cândida Pamplona, filha do tabelião Cândido José Pamplona, contava várias gerações de antepassados luso-cearenses, era irmã do comendador Iclirérico Narbal Pamplona, também deputado provincial, e sobrinho de Frederico Augusto Pamplona, também deputado provincial que presidiu não só sua província, como a do Rio Grande do Norte" (Nava, 1987, pp. 25, 27, 39).

As viagens à Europa, que "requintaram" a mentalidade dos avós aliadas às "desgraças" do Nordeste, levaram-nos a se deslocar para o Rio de Janeiro em 1878. No mesmo período, outros segmentos do grupo familiar migraram para o Rio de Janeiro.

O pai de Pedro Nava nasceu e teve a primeira escolarização ainda no Ceará, onde recebeu a influência de "esplêndidas figuras" que constituíam o conjunto de "parentes" e "amigos" e que "ajudaram a configurar sua personalidade", dando-lhe as características de "aristocracia" e "intelectualidade". Influência igualmente importante teria sido a participação numa "sociedade secreta" maçônica freqüentada pelos "intelectuais" e políticos da província. Em 1896, com vinte anos, deslocou-se para a Bahia para cursar farmácia e medicina. Logo depois se transferiu para a faculdade do Rio de Janeiro, onde se formou (idem, ibidem, pp. 84-101).

Por outro lado, o avô materno de Pedro Nava — "agrimensor, construtor, empreiteiro, ferroviário, político, jornalista, funcionário e educador" - havia se estabelecido em Juiz de Fora e se integrado à oligarquia local como fazendeiro. Minas Gerais abriga, assim, um outro feixe de vínculos familiares, em conjunto com o Ceará e o Rio de Janeiro. Juiz de Fora foi o local onde o pai exerceu a profissão, para onde o grupo familiar restrito se transferiu e onde Pedro Nava nasceu e passou parte da infância. Mas o Rio de Janeiro é o centro geográfico da rede familiar. Dessa forma, os deslocamentos geográficos não significam subtração de laços, mas adição de novos segmentos. No final do século passado, as "doenças, necessidades, obrigações, compromissos, acaso, destino ... fizeram convergir para o Rio de Janeiro gente da família de meu pai, de minha mãe. Os parentescos e amizades começaram a tecer a teia dos conhecimentos e dos amores" (idem, ibidem, pp. 303, 209). Outras partes do grupo familiar remanescentes no Ceará também se transferiram para o Rio de Janeiro, devido aos conflitos políticos que inviabilizaram sua condição de funcionários públicos ou juízes lá. 
O deslocamento do pai de Pedro Nava para Juiz de Fora, em conseqüência do casamento, em 1902, inseriu-o num clã ou numa "roda de primos de primas e amigos de primas" de fazendeiros e políticos locais. Um levou-o para clinicar, e este "era o processo do médico se fixar no interior. Apadrinhado por um fazendeiro que lhe dava o partido de sua fazenda e da dos amigos da redondeza. Dessa forma já se chegava com clínica feita e área de atividade demarcada. Era só esperar o dinheiro." No entanto, a aliança matrimonial pôs em confronto estilos de vida: descendente "de uma familia citadina, filho de um comerciante liberal, meu pai assim que conheceu melhor a sogra rural, escravocrata, dominadora e violenta, tomou-lhe horror". Apesar disso, o clínico apadrinhado tornou-se também diretor de Higiene, presidente do Liceu de Artes e Ofícios, professor e diretor do hospital em Juiz de Fora. Pouco antes de morrer, aos 35 anos, em 1911, seu pai voltou a residir e trabalhar no Rio de Janeiro, como médico funcionário público, "apesar das tentativas da política dominante em Juiz de Fora para impedi-lo". Reaproximou-se, então, dos colegas, dos "companheiros de faculdade" (idem, ibidem, pp. 231, 255, 384-5) e dos parentes dos quais havia se distanciado (idem, 1973).

Após a morte do pai, o grupo familiar restrito de Pedro Nava deslocou-se novamente para Minas Gerais, dessa vez para Belo Horizonte, onde sua mãe tinha emprego nos telégrafos. Foi nessa teia de relações de parentesco, de amizade e profissionais, distendida pelos deslocamentos geográficos por Ceará, Rio de Janeiro, Belo Horizonte e Juiz de Fora, que ocorreu a trajetória social e profissional de Pedro Nava. Da utilização deste conjunto de redes, do constante jogo de alianças e as conseqüentes amizades e inimizades resultaram sua ascensão social e todos os seus títulos.

Praticamente todas as reconversões ou redirecionamentos na trajetória de Pedro Nava estão assentadas na utilização de uma ou mais relações de reciprocidade, que abarcam as vinculações de parentesco, amizade, política ou patronagem profissional, entre outras. Trata-se, no caso, de uma "família segmentar", na definição utilizada por Cole e Wolf $(1971$, p. 264 e passim). Porém, as formas de utilização do parentesco e suas relações com outras esferas, tais como a "amizade instrumental" (Wolf, 1980) e a política, variam muito, e dependem inclusive do estágio em que se acha a trajetória e das posições sociais dos diferentes segmentos da família. Ou seja, as esferas profissionais, escolares, políticas etc. são vistas e acionadas como prolongamento das relações de parentesco, mas os segmentos de parentes têm poder distinto nestas esferas, variando, portanto, sua utilização conforme os respectivos problemas e objetivos.

A fase escolar de Nava começou em 1914, em Belo Horizonte, no Ginásio Anglo-Mineiro, criado quando "figuras importantíssimas 
20) Para os componentes do primeiro período, praticamente não há aparelho escolar formal. Em geral, a escolarização secundária depende de organizações religiosas, militares ou de algum mestre particular. Quanto aos membros nascidos entre $1835 \mathrm{e}$ 1850, dos cinco com informaçōes disponíveis, três se formaram no Colégio Pedro II. Essa proporção eleva-se para 11 do total de 16 nascidos entre 1895 e 1904 . Entre os 71 membros da academia para os quais temos informações, da fundação até 1989,25 fizeram os estudos secundários no Colégio Pedro II. Ver Coradini (1994). intentavam dotar a cidade de uma instituição moderna para nela matricularem seus meninos". Durou apenas dois anos a experiência. Após passar por outros colégios, em 1918 tornou-se interno do Colégio Pedro II, no Rio de Janeiro. Este é o colégio de formação secundária de boa parte dos componentes da Academia Nacional de Medicina de sua geração. ${ }^{20}$ Segundo Nava, tudo "o que há de mais ilustre na vida brasileira recebeu seu influxo e criou-se no seu espírito ... assim como são inconfundíveis, na Inglaterra, os homens que estudaram nos colégios de Cambridge e Oxford, na França, os que foram alunos de Stanislas e de Louis-le-Grand, no Brasil, os que tiveram a honra de passar pelo velho Pedro II, dali trouxemos o espírito da casa", formando uma "cadeia que nos une numa imensa e secular família espiritual" (idem, ibidem, pp. 151, 341).

Porém, o ingresso neste internato requeria 'vestibular' e o que aprendera no Anglo era muito precário. Entretanto, por ocasião do exame, um dos componentes da banca "se interessou mais pelo meu nome que por minha leitura e análise". Isso porque uma das suas tias havia sido colega do referido professor e, diante de sua "benevolência", os demais membros da banca fizeram o mesmo, e Nava foi "aprovado com uma quase distinção" (idem, ibidem, p. 335).

Após o exame, quando se tratava de obter "matrícula gratuita", foram acionadas as vinculações dos tios pertencentes ao segmento nordestino da família, cuja presença no Rio de Janeiro, como um misto de "funcionários públicos", "intelectuais" e "políticos", era o resultado das lutas de facções entre as classes dominantes locais. ${ }^{21}$ Um desses tios recorreu a um senador, com o argumento de que se tratava da matrícula de alguém que havia "passado bem no vestibular e era filho de funcionário civil morto no trabalho". Mas o senador dispensou as "explicações" e, num contato com o ministro, "arranjou" tudo (idem, ibidem, p. 336).

Já no Colégio Pedro II, Nava decidiu estudar medicina. Pesou a morte do pai e o fato de a mãe passar a morar em Belo Horizonte, onde em 1912 foi criada uma faculdade de Medicina. Nava ingressou na primeira turma. Já se havia inserido nas rodas mundanas ou boêmias e intelectuais da cidade, que posteriormente tiveram efeitos em suas atividades como escritor. Porém, a viuvez da mãe resultava em dificuldades financeiras. Vivia ela "da inclústria dos sabões domésticos, da revenda de rendas do Norte, da mesada de meus tios paternos e de dar lições de datilografia" (idem, 1976, p. 339).

Esta situação obrigou Nava a arranjar "um pequeno emprego com folgas que me permitissem continuar na escola", visto que o parente na casa do qual moravam "não tinha mais as migalhas de influência política que desfrutara em Juiz de Fora. Os amigos de 
Belo Horizonte eram recentes demais para deles se pedir favor ... . Foi então que escrevi a meu tio Antônio Sales", o qual tinha influência política no Ceará. Obteve três cartas de recomendação do presidente do Ceará, "amigo" do tio, sendo uma para o presidente de Minas Gerais e as outras para dois secretários de Estado. Apenas uma carta surtiu efeito: aquela endereçada ao secretário do Interior de Minas Gerais, Afonso Pena Júnior, que conhecera seu pai em Juiz de Fora, "interessando-se" pelo conjunto de sua "família". E assim o secretário ordenou a um subordinado, diretor de Higiene, a contratação de Nava, que saiu do encontro apertando "a mão generosa ... para sempre escravo" (idem, ibidem, pp. 340, 345, 346).

Desse modo, ingressou no exercício profissional. Apesar de ser um dos poucos componentes da Academia de Medicina a se proclamar "ateu" ( $O$ Globo, 15.5.1984, p. 25) e originário de uma família com passado "maçom" e "liberal", o fez através daquilo que ele mesmo caracterizou como "a idéia catoliquérrima do crime e castigo, do prêmio e da virtude. A demissão, a transferência, o ostracismo, a justiça. As eleições, os cartórios, as tarefas, o pão-de-ló" (Nava, 1976, p. 302). Atribuiu tudo isso aos políticos profissionais do período, que tinham "uma mentalidade de comandita", lembrando que o "oficialato de gabinete ensinava a cortesia, a habilidade, a lábia, o jeito de mandar embora, de evitar contrariedades a suas excelências". Entre as conseqüências figurava o "exilio final dos ex-potentados para o Rio de Janeiro". Para "evitar esses inconvenientes cultuava-se o presidente do Estado" (idem, ibidem, p. 300).

À primeira vista, a crítica à politicagem dominante parece estar em contradição com a utilização dela para a obtenção de postos. Mais que isso, trata-se de ambivalência que sobressai por figurar tão explicitamente nas memórias de um intelectual. $\mathrm{Na}$ cultura erudita no Brasil, pelo menos no período de elaboração destas memórias, já era do senso comum dos intelectuais (no sentido brasileiro qualificado por Pécaut, 1990) a crítica ao coronelismo, à politicagem etc., ou seja, às formas de exercício da política eleitoral tidas como tradicionais. Porém, a ambivalência que se observa em Nava decorre principalmente da concepção de política vigente, baseada nas relações de reciprocidade. $\mathrm{Na}$ medida em que todas as esferas de relações sociais são concebidas como extensões das relações de reciprocidade e seus correlatos, como a amizade, a bondade, a sociabilidade, o humanismo, valores por definição personificados e particularísticos, as críticas aos desmandos da política circunscrevem-se aos efeitos mais evidentes e brutais de seu exercício, como a violência e as perseguições políticas, sobretudo no plano eleitoral.

Não se trata aqui somente da velha questão das relações entre público e privado, tão enfatizada pelas filosofias políticas. Trata- 
se do exercício do poder, seja político ou não, concebido com base em relações de reciprocidade e conseqüente segmentaridade, a começar pela própria família. $\mathrm{Na}$ medida em que as relações de parentesco são segmentares e as demais relações sociais são concebidas como extensão delas, "tudo passa a ser político" em sentido difuso (Cole e Wolf, 1971). Ao mesmo tempo, a política oficial, objeto de críticas, restringe-se ao jogo das alianças eleitorais. No caso em pauta, a postura crítica face aos esquemas eleitorais combina-se tanto com a utilização da influência política de parentes e amigos para a obtenção de postos, como com a concepção do exercício profissional, da própria carreira e consagração social como sucessão de alianças e amizades, e sua contrapartida, as traições, inimizades, boicotes e vinganças.

Isso se observa já no primeiro emprego de Nava, obtido através da mediação do secretário do Interior de Minas Gerais. O diretor de Higiene, subordinado ao secretário, com certo poder de controle do trabalho, obrigado a aceitar a contragosto a "ordem de contratação", "vingou-se impondo a Nava as mais difíceis missões". Este, por sua vez, pôde se "vingar" mais tarde, em suas memórias (Salles e Gama, 1987, p. 104) e através de outros recursos, como na eleição do antigo chefe como membro honorário da Academia Nacional de Medicina (Nava, 1987, p. 372; Boissevain, 1977, p. 280).

Logo depois, Nava conseguiu transferência para Juiz de Fora, onde, a exemplo de seu pai, foi nomeado para o centro de saúde. Naquela cidade, teve atritos com facções políticas e com médicos locais. Pouco tempo depois, resolveu atuar de novo em Belo Horizonte. Acionou outra vez os representantes da política estadual e, mais especificamente, seu mediador com o então presidente do estado, obtendo, assim, a transferência. Além de reassumir o posto na secretaria do Interior e os atritos com o antigo chefe, montou consultório com um antigo amigo e colega e passou a atuar também no hospital da Santa Casa. Posteriormente, Nava e o amigo foram

"nomeados para assistentes voluntários da segunda cadeira de clínica médica da Faculdade de Medicina da Universidade de Minas Gerais. ... Tinham subido o degrau mais difícil, o primeiro da carreira magistral. Tudo trabalho do Ari Ferreira. Como o Samuel aparecesse pouco na sua enfermaria e o Marcelo só viesse para dar as suas aulas, a parte administrativa do serviço era resolvida de comum acordo entre os assistentes efetivos" (Nava, 1987, pp. 312 e passim, 371 e passim, 402).

Ou seja, através da mediação de amigos já assistentes.

Mas apesar da ascensão profissional e social em Belo Horizonte e da ampliação da rede de amigos decorrente de seu "trabalho mundano", acabou se transferindo para o interior de São Paulo, 
por diversos motivos. Um dos mais imediatos foi a "morte trágica de sua última paixão", que lhe infundiu "horror às ruas e a tudo em Belo Horizonte" (Salles e Gama, 1987, p. 104; Nava, 1983, pp. 100-1). O segundo motivo foi a descoberta de que o concurso que pretendia realizar na faculdade de medicina local já tinha outro candidato "pré-escolhido". Insistiam para que se inscrevesse para servir de boi de piranha, ou seja, para legitimar o concurso viciado. Nas memórias escritas posteriormente, qualifica a decisão de abandonar Belo Horizonte como sua "primeira grande burrada na vida" (Nava, 1983, pp. 102, 101).

Nesta nova ruptura e reconversão profissional para 'médico da roça', a política não foi acionada diretamente, já que ia como médico clínico. O principal recurso social utilizado neste caso foram as vinculações de amizade e parentesco com um antigo colega, "seu amigo Cavalcanti, que iniciara próspera clínica no oeste paulista ... Nava lá chegando logo abriu consultório de clínica geral, praticando obstetrícia”, apesar de ter se especializado em pneumologia (Salles e Gama, 1987, p. 104; Nava, 1983, pp. 100-2 e passim).

Porém razões políticas o levaram, pouco tempo depois, a trocar São Paulo pelo Rio de Janeiro. Nesse caso, lutas partidárias e ideológicas: "por ocasião da Revolução Constitucionalista em 1932, tendo optado pela bandeira de Getúlio Vargas, entrou em dissonância com os paulistas ... e não teve mais ambiente naquela cidade" (Salles e Gama, 1987, p. 104). Um segundo motivo apressou a decisão de se transferir para o Rio: as dificuldades como médico clínico e, particularmente, a "inabilidade como parteiro", além da possibilidade de "fossilizar-se" na roça (Nava, 1983, p. 235). Naquele contexto político, Nava manteve sua adesão à "revolução de 30 ", mas o amigo e parente que servira de mediador para seu ingresso profissional naquele lugar aderiu ao movimento constitucionalista de 1932, portanto, a uma facção contrária, tornando-se posteriormente político profissional, com diversos cargos eletivos. Apesar de terem continuado amigos por toda a vida, com fortes vínculos de reciprocidade, os conflitos de Nava com as chefias políticas locais tornaram inevitável a transferência para o Rio de Janeiro (idem, ibidem, pp. 259-70).

$\mathrm{Na}$ capital federal, contava já com recursos sociais - as relações de parentesco, a amizade de antigos colegas de escolarização secundária $e$, inclusive, antigos amigos e colegas médicos de seu pai (Nava, 1973, 1983). Entretanto, para inserir-se na profissão e nas esferas de consagração social, e para obter postos, precisou recorrer direta e intensamente à política, agora no sentido de mediação burocrática e profissional. Como narra o próprio Nava (1987, p. 478), chegando à capital, em 1933, foi morar com os tios, começando em seguida a 
"traçar com os amigos planos de minha permanência no Rio. Logo, por intermédio de Afonso Arinos e Rodrigo obtive de Virgíliode Melo Franco carta decisiva para Pedro Ernesto (então prefeito do Rio), pedindo meu aproveitamento nos quadros da Assistência Pública Municipal ... . Como eu preferisse a Saúde Pública, para seguir os passos de meu pai, guardei a carta como um trunfo, para usá-la, depois de procurar Washington Pires, então titular do recém-criado Ministério da Educação e Saúde. Eu tinha sido seu discípulo de neurologia e com Joaquim ... Cavalcanti e Francisco de Sá Pires éramos dos alunos que freqüentavam sua casa para longas conversas noturnas."

Estes planos envolveram a utilização de um intenso trabalho anterior de mobilização de amigos quando ainda estava em São Paulo, alguns "muito por dentro da vida médica do Rio de Janeiro", aptos, portanto, a lhe fornecerem pistolão e a movimentar "amigos poderosos" (idem, 1983, p. 174). Logo após sua chegada ao Rio, passou a desenvolver intensa atividade de visitas a médicos antigos e colegas, alguns em postos de destaque ou já convertidos em celebridades na Academia de Medicina (idem, ibidem, pp. 284-6 e passim). Visitou, também, políticos que poderiam servir de pistolões ou mediadores, em geral antigos amigos e/ou colegas, como os Melo Franco.

A tentativa de aproveitar a ligação com o ministro fracassou: "confundi aquela cordialidade com amizade e esperava tudo do professor de Belo Horizonte". Após um jogo sutil de apresentação e pedido de emprego, a resposta foi "que era impossível ..., as vagas mal chegavam para os gaúchos com o viático de Getúlio, para os amigos do Olegário com o dito do Palácio da Liberdade" (idem, 1987, p. 480). Foi então procurar o prefeito, que leu (idem, ibidem, p. 481):

"com atenção a longa carta de Virgílio. Encarou-me sorrindo e sem hesitação certificou que eu seria nomeado ... . E quando eu ia abrindo a boca ele estendeu a mão me interrompendo. Não me agradeça ... . Agradeço eu ... porque graças a você vou ter a oportunidade de prestar um serviço ao Virgílio .... Duas audiências ... a primeira serviu-me para encerrar uma amizade, a segunda, para começar a seguir um dos melhores homens que já encontrei."

Os Melo Franco, que se constituíram em um dos principais pistolões ou mediadores de Nava no Rio de Janeiro, compõem um clã de políticos e intelectuais, no sentido brasileiro (Pécaut, 1990), com base geográfica original em Belo Horizonte. Como diz Nava (1983, p. 325), os intelectuais e políticos amigos dos mesmos são "um desfilar de nomes de velhos conhecidos comuns 
de Minas, de políticos desse estado e do resto do Brasil". Neste clã, um de seus melhores amigos, Afonso Arinos de Melo Franco, é definido como poeta, ensaísta, crítico, cronista, historiador, biógrafo, memorialista, tratadista de direito, teórico, político, revolucionário, oposicionista, secretário estadual, deputado, senador, embaixador, mineiro, brasileiro e ibero-americano, em resumo, um "político", "professor" e "homem de letras" (Nava, idem, pp. 390, 405). Além disso, provinha "de uma família de letrados, o que era sinônimo, no Brasil, de pessoas de educação e sabedoria francesas" (idem, ibidem, p. 409). A amizade com os Melo Franco teve início na educação básica, em Belo Horizonte, prosseguiu no Colégio Pedro II, no Rio de Janeiro, e se estreitou na vida mundana e intelectual da capital mineira.

Após o ingresso no serviço público, a exemplo dos demais componentes da Academia de Medicina, Nava foi sucessivamente chefe de diversos serviços e diretor de hospitais e burocracias públicas (tais como o Hospital Carlos Chagas e o Hospital dos Servidores do Estado). Logo realizou concurso para a Faculdade de Medicina do Rio de Janeiro, estabeleceu consultório particular e passou a "freqüentar o serviço" de médicos consagrados, entre eles Aluízio de Castro, acadêmico também e colega de faculdade. $\mathrm{Na}$ França e Inglaterra especializou-se em reumatologia e, mais tarde, fundou a Sociedade Brasileira de Reumatologia, de onde se originaram seus principais "títulos associativos". Simultaneamente, intensificou as atividades de escritor e memorialista e ingressou na Academia Nacional de Medicina.

Nava atuou em hospitais privados, principalmente na Policlínica Geral do Rio de Janeiro, onde foi chefe de unidade, sócio benemérito, chefe de serviço, diretor e presidente. Se no caso do setor público foi decisiva a mediação política, neste caso a patronagem também determinou o ingresso e $\mathbf{a}$ ascensão. A política dá lugar aqui à patronagem profissional, como o próprio Nava explica. Em 1898, um amigo do pai "levou-o para trabalhar na Policlínica Geral do Rio de Janeiro, já então feudo da família Moura Brasil". Moura Brasil Filho pertencia à turma em que o pai de Nava se formara e era muito ligado a ele (idem, 1973, pp. 216, 225). Além disso, em 1899, um tio foi "interno, assistente e chefe de clínica do velho Moura Brasil, na Policlínica Geral do Rio de Janeiro" (idem, 1986, p. 74).

Tal como a inserção e ascensão profissional no setor público e no privado, o ingresso de Nava nas esferas de consagração profissional e social, como a Academia Nacional de Medicina, é concebido e implementado com base em relações de amizade, ou seja, reciprocidade e patronagem. Nesse caso, há também uma série de críticas às traições, deslealdades ou blefes. Mas mesmo esta oposição está sempre referida aos princípios da 
reciprocidade, tais como amizade, lealdade, confiança, bondade etc. Assim, logo após chegar ao Rio de Janeiro, ao mesmo tempo em que mobilizava as vinculações de que resultariam o seu capital social e os recursos para ingressar e ascender na profissão, desenvolvia, concomitantemente, esforços com o objetivo de se aproximar de mestres ou figuras ilustres ligados ao magistério e à Academia de Medicina.

Tendo isso em vista, passou a assistir semanalmente às sessões da academia, quando os

"mais assíduos eram justamente os mais velhos, quase inválidos, que tendo deixado a clínica ou sido deixados por ela, ... empregavam seu tempo ... nas intriguinhas profissionais, na conspiração barata, na maquinação mesquinha ... . Viviam com a idéia fixa nas próximas eleições e no lugar que iam pleitear para eles próprios ou para os do seu parentesco nesta ou naquela vaga. Varrera-se-lhes da mente qualquer idéia de amizade e o que os ligava uns aos outros era o troca-troca de influências e o pensamento posto no negócio cru, nunca expressado mas sempre presente" (idem, 1983, p. 347).

Ao lado destes, que classificava como "marrons", havia "um segundo grupo de homens de meia-idade ... . Esse era o que dava vida à academia." Quando Nava pensou em desistir da pretensão de ingressar na academia, seu amigo (posteriormente presidente da academia) garantiu-lhe que o ingresso dependia de "trabalho" que não precisava "ser muito", bastava que fosse "badalado", feito com "habilidade" (idem, ibidem, pp. 348, 353-4).

A classificação negativa dos "médicos marrons", por oposição aos "brancos", reiterada constantemente por Nava - foi inclusive subtítulo de um volume das memórias (Nava, 1973) —, não incluía a utilização das vinculações de reciprocidade e patronagem. Desse modo, tal como na política, o objeto de crítica restringia-se ao blefe ou "negócio cru", isto é, às trocas recíprocas sem o código da lealdade e da amizade que tornavam esse tipo de relação legítimo e louvável.

"Antigamente e em tempos de maior respeito dos médicos uns pelos outros havia, na Academia Nacional de Medicina, um princípio sagrado. Chegado a certo tempo de serviços prestados à instituição, os acadêmicos que o queriam solicitavam sua passagem para o quadro dos primeiro chamados 'honorários' e depois 'beneméritos' ... . O que queria ser investido nesta classe declarava-o em carta ao presidente da instituição e mandava esta por intermédio do que ele desejava fosse seu sucessor: algum filho, também médico e de valor; assistente cheio de méritos; 
médico mais jovem de sua admiração ou de quem queria exaltar as qualidades ... . Este fazia suas visitas, obtinha as anuências necessárias e então entregava a carta ao presidente que declarava aberta a vaga. Era considerado de boa ética ninguém negar o voto ao preferido do titular paraninfo e também não havia nenhum atravessador que ousasse se inscrever em circunstâncias tão especiais. $O$ candidato, nestes casos, tinha sua eleição assegurada: era simples sucessão de um diádoco aceito por todos. Mas os costumes da boa convivência médica vêm se degradando...! e a praxe que descrevemos aos poucos foi sendo desobedecida e passou a haver o hábito dos desafetos do titular da cadeira aproveitarem a ocasião de levantarem outra candidatura" (idem, 1983, pp. 354-5).

Ou seja, os critérios legítimos de sucessão são os das diferentes manifestações da patronagem, tais como a cooptação, o nepotismo etc. $O$ alvo da crítica não são as vinculações de reciprocidade, a patronagem e o particularismo apresentados como "princípio sagrado", com "ética" própria, mas a "degradação" deles pelos "atravessadores", os que concorriam por fora, rompendo o código e o ritual da reciprocidade.

Apesar da "degradação", Nava conseguiu acumular "amizades" suficientes para ser eleito para a academia. Fora apresentado a muitos membros da casa e "se dera a conhecer aos que tinham amigos ou relações de sua gente. Alguns ... tinha visto menino", outros tinham sido "amigos" de seu próprio pai, outros ainda, "conhecidos e aparentados" de sua "família". Os nomes são recordados nas memórias (idem, ibidem, pp. 357-8, 359), como pagamento de "dívidas de amizade", evocando-se aí a sucessão quase infindável de "amigos de amigos" que compõem as redes de trocas e reconhecimentos recíprocos.

Numa avaliação retrospectiva de sua carreira, Nava (1987, pp. 81-2, 97) destaca que foi "interno" de diversas disciplinas, "monitor, estagiário, assistente, chefe de serviço, professor livre, catedrático, emérito e bonoris causa. Para servir, aceitei, três vezes, encargos de administração médica." Um destes foi a "chefia de um serviço", conquistado "mercê da justiça de Clementino Rocha Fraga" (médico consagrado, membro da academia e pai de outro acadêmico). Com isso, chegou "aonde queria e sonhara. E seria patron durante 35 anos até que essa situação me fosse roubada por uma maquinação suja." Ela teria sido motivada pela "maldade ou mero desejo de se vingar de quem lhe era hierarquicamente superior." Foi assim que "desencadeou-se todo um mecanismo de solapagem" no hospital onde Nava trabalhava, sem entender ainda a "organização subterrânea de sua maçonaria" (idem, 1983, p. 513). 
Se, por um lado, todos esses postos e títulos foram o resulta-do de trunfos fornecidos pelas alianças com base na proclamada amizade, que chega a ser apresentada como "título" (idem, 1987, p. 94), por outro, resultaram em muitas inimizades. $O$ próprio "trabalho mundano" é avaliado com base nestes critérios, do que decorre o cálculo dos "custos" do jogo da "amizade" e "inimizade" e das respectivas "qualidades humanas" envolvidas. Para Nava (1983, p. 401), o "que há de terrível na vida mundana é a perda de tempo - a troca inútil de visitas, jantares e almoços de cortesia ... tudo isso é motivo de encontros tantas vezes desagradáveis com outros que não os verdadeiros amigos". Porém, com os "amigos", os "irmãos de espírito, a coisa é diferente. ... Tratandose deles, não há perda de tempo."

Se se comparar as memórias de Nava com os documentos da Academia Nacional de Medicina, particularmente os mais solenes, tais como discursos, orações e elogios, de qualquer período, o que mais se destaca são as semelhanças não apenas estilísticas, mas de temas, de atributos pessoais louvados, em especial a amizade, as relações personificadas vividas e o objetivo de consagrar o objeto de louvor. A principal diferença é que, nestes documentos, por seu caráter mais oficial e ritualizado, a amizade e os atributos pessoais que a propiciam, como a bondade e a generosidade, estão sempre em destaque, mas as inimizades, ainda que explicitadas com freqüência, raramente são detalhadas. Já nas memórias, precisamente por seu caráter de confissão (e mesmo vingança), a inimizade ou as qualidades humanas que a geram se apresentam como contrapartida permanente, sem rebuços.

Ao suicidar-se em 1984, Nava deixou uma correspondência para os amigos, na qual admitia que submetessem seu corpo a rituais religiosos, apesar de "proclamar-se ateu" (Coradini, 1994). Aludia "aos problemas que teve no campo profissional, como médico", e pedia: "se a Academia Brasileira (sic) de Medicina, a Policlínica Geral ou o Hospital de Servidores do Estado mandarem coroas, estas deverão ser devolvidas imediatamente" ( $O$ Globo, 15.4.1984, p. 25). Não por coincidência, foram estes os três principais locais onde atuou profissionalmente.

Toda esta inimizade é a contrapartida da importância atribuída à amizade enquanto regra de organização social e profissional. Mas de onde provém tal concepção? Ao que tudo indica, um de seus componentes é a própria concepção de medicina, baseada no carisma e, conseqüentemente, na figura do patron que, "no sentido médico do termo, ... não é propriamente patrão, mas o chefe, o mestre que convém seguir e a cujo exemplo nos moldamos profissionalmente" (Nava, 1976, p. 323). Com base nisso, classifica os médicos segundo suas "qualidades humanas", em duas cate- 
21 Apesar do cleslocamento de segmentos do grupo familiar para o Rio e Minas, a família continuou a ter importância política no Ceará, se bem que como dissiclência das oligarquias locais politicamente dominantes. Assim, por exemplo, quando o pai de Nava morreu, seu tio, deputado estadual, apresentou à Assembléia Legislativa "moção de pesar", que foi aprovada e que provocou um conflito com o presidente da província, de uma facção rival. O tio deputado renunciou ao mandato (idem, pp. 268-9). O "tio Salles" que tanto influenciou Nava era um funcionário público que se transferiu do Ceará para a capital federal devido às dissidências entre as facções políticas locais. No Rio e em outras cidades atuou como escritor, jornalista, militante político, tendo sido membro da Academia Brasileira de Letras (Nava, 1986, p. 322). gorias: o "santo, o sábio, o heróico, o desprendido, o dedicado, o sincero, o altruísta ... - o homem de branco. E o pérfido, o imprestável, o ignorante, o comodista, o rapace, o egoísta, o fariseu ... - o médico marrom." ${ }^{21} \mathrm{~A}$ amizade entre médicos é "difícil", fato que Nava atribui à ineficiência da medicina e, por outro lado, à necessidade de manter uma imagem social através da mistificação, resultando, entre os médicos, no "ódio social, convivente, feito de encontros, reuniões, mesas-redondas, simpósios, sociedades, federações, academias" que constituíam, todas, mera "ocasião do aniquilamento do outro" (idem, 1987, pp. 82, 87).

Esta concepção carismática da profissão, das relações entre os pares, abarca, também, as relações entre discípulos e mestres, estes considerados "na altura em que tenho a imagem de meus pais ..., dediquei-lhes nos meus livros as palavras com que pretendi honrá-los e tornar duradoura sua lembrança. Tive meus alunos como filhos ... tentei ser para eles um pai e não merecia o que me veio de alguns." É por essa ótica que Nava classifica os assistentes em três categorias: "os inimigos natos", "a grande massa dos indiferentes" e "os que se tornam amigos do chefe e talham preito de lealdade, gratidão e bem-querer com ele". (idem, ibidem, pp. 83, 90). Além disso, identifica entre os colegas uma série de clivagens e oposições entre facções, tais como os médicos antigos e os novos, admitidos por critérios distintos, ou clivagens político-ideológicas, em que se encaixavam os vinculados a determinadas ideologias e aos movimentos de esquerda, sem falar nas facções baseadas diretamente nas "redes", "afinidades" ou "qualidades humanas" (idem, 1983, p. 416 e passim).

Como não se trata apenas de um médico clínico, mas de um componente da elite e da academia, com atuação na esfera pública, essa concepção carismática da profissão é insuficiente para explicar a presença de relações de reciprocidade em todas as esferas onde atuou. Embora tenha destacado que "nada devo ao acaso, à sorte, ao bambúrrio, ao cambalacho, aos compadrios, às proteções" (idem, 1987, p. 84), toda a carreira de Nava foi condicionada pelas relações com a política e a patronagem. Sendo assim, a concepção de profissão deve ser considerada em conjunto com a própria concepção de política.

Há, em primeiro lugar, a mencionada influência política, como principal recurso para o acesso a postos e, conseqüentemente, para a valorização do título escolar numa relação privilegiada com o mercado profissional. Neste nível mais geral, há uma interseção das vinculações de parentesco, de amizade, com o facciosismo político-eleitoral e com as burocracias públicas, em combinações variáveis, mas tendo sempre como base as relações de reciprocidade. Em segundo lugar, num nível mais profissional 
22 Num discurso proferido na academia, em 1959, por exemplo, diz que seu objetivo era a criação de "uma imagem sublimada de si mesmo", como um "emblema ... sobre essa contrafação generosa e prudente, devemos construir o mito do 'documento declarado'. Não pode haver nada mais acadêmico do que isso." Ver Brazil Médico, nov.-dez. 1959, p. 11. Suas memórias, como as de Marcel Proust, teriam um sentido "cultural", na medida em que serviam para compreender a história de sua época, declara em entrevista a Aguiar (1994, p. 129). Para mais cletalhes, ver principalmente Nava (1973). Sobre as autobiografias como "empresa de celebração da família" e componente fundamental das estratégias de reprodução do capital "social", ver Saint Martin (1980, p. 5). ou da carreira, há uma interseção entre princípios ou lógica das lutas político-eleitorais, da carreira médica e das burocracias públicas, igualmente baseada em relações de reciprocidade.

Para mencionar apenas um exemplo, relativo a Nava, na organização "político-administrativa" dos serviços de saúde em que atuava, "a formação de uma equipe obedecia primeiro às imposições do prefeito, da sua entourage, dos deputados, dos vereadores, dos chefes políticos, dos cabos eleitorais, depois do secretário de Saúde e Assistência, do seu gabinete, do diretor de Assistência Hospitalar, do diretor do hospital e no fim, e só então, da vontade e da escolha do chefe de serviço". E no âmbito dos próprios médicos e de suas hierarquias havia também "o jogo", e este é o do "dom" e "contradom". Nas palavras de Nava (idem, pp. 97, 91), se o "chefe de serviço como eu fui ... recebe, pelo Natal e pelo seu aniversário, três garrafas de uísque estrangeiro", quando "diminuírem para duas, atenção! para uma, alerta! que teu presenteador está começando a se sentir seguro. Quando esse uísque for substituído por oferta de vinho nacional - manda embora o furbo ou prepara-te para cair, o que acontecerá fatalmente quando receberes de festas só votos telefônicos."

Vê-se assim que à concepção carismática do exercício da medicina se acresce uma concepção de política baseada em relações de reciprocidade ou de amizade, com as conseqüentes tensões e conflitos. Mas, além de ser médico clínico e gestor de burocracias públicas, vivenciando suas interseções com a política, Nava representa também o cientista componente da Academia de Medicina e o escritor inserido na cultura erudita. Como já se tentou demonstrar (Coradini, 1994), o recrutamento para a academia se pauta pelos mesmos princípios e critérios baseados nas relações de reciprocidade que respaldam a ascensão profissional e social. Porém, nesse caso, como envolve uma concepção de realização profissional com base em qualidades humanas, a principal função da academia seria eternizar em monumentos os vultos que encarnaram estas qualidades, em geral, com referências a autores clássicos franceses, o que, a exemplo das próprias memórias, é visto e apresentado como cultura. É isso que Nava enfatiza e explicita, como orador oficial, ao defender a academia enquanto construção e eternização da imagem social de seus componentes. ${ }^{22}$

O recrutamento da elite médica ou cultural através de critérios particularísticos evidentemente não ocorre só no Brasil. Já foi demonstrada, por exemplo, a utilização de critérios étnicos e patronagem profissional (Hall, 1948) ou do autocontrole profissional (Freidson, 1984) nos Estados Unidos, ou os usos do patrimonialismo na Tailândia (Maxwell, 1975). Analogamente, no tocante às elites culturais brasileiras, descrições etnográficas já evidenciaram seu 
entrecruzamento, a existência de um código de interconhecimento e critérios informais de recrutamento, nos casos do Conselho Federal de Educação, do Instituto Histórico e Geográfico Brasileiro e da Academia Brasileira de Letras (Quintella, 1984). A concepção de política como luta entre "amigos e inimigos" e as relações disso com as estruturas de clientelismo no Brasil também foram evidenciadas em estudo sobre os políticos profissionais (Grynszpan, 1990).

O que o caso em pauta tem de mais instigante é o fato de se referir aos componentes da Academia Nacional de Medicina, a qual, na inexistência de um campo científico, representa o que há de mais próximo à racionalidade deste. Como já foi destacado, para apreender a dinâmica da institucionalização da profissão no país e o recrutamento de sua elite, é necessário ter em conta que o processo de importação das filosofias e tecnologias médicas não requer a importação simultânea do ethos correspondente. $O$ que mais se destaca no caso apresentado é, em primeiro lugar, o fato de que as relações de reciprocidade se intensificam no século $\mathrm{XX}$, quando se supõe que teriam arrefecido. Em segundo lugar, isso não impede que produtos dos avanços técnicos do campo científico, em geral, ou da medicina sejam importados e incorporados, o que pode até modificar os perfis das carreiras, mas sem entrar em confronto com as concepções vigentes. Em terceiro lugar, as posições críticas relativamente à política tradicional, no que têm de violência física e desmandos, não impede que se apliquem exatamente os mesmos princípios em novas condições mais intelectualizadas e escolarizadas.

Deixo em aberto uma questão: ao que se pode atribuir a reprodução social de concepções profissionais e intelectuais com base na reciprocidade. Uma hipótese atrativa, mas ainda não comprovada, reporta-nos às condições de concorrência no recrutamento destas elites. Posso afirmar, no entanto, que o caso em pauta não se adequa nem às conclusões de Collins (1979), de que a escolarização norte-americana é o resultado menos de requerimentos técnicos do que das lutas pela supremacia moral e étnica, nem aos trabalhos de Bourdieu (1984) acerca da luta entre diferentes ethos de classe e expectativas correspondentes quanto à ascensão social pela escolarização. Trato de elites qué; ao menos no período considerado, não sofreram a concorrência de nenhum outro princípio de hierarquização que as ameaçassem. Isso não significa que não haja concorrência interna, porém ela sempre aparece baseada em relações de reciprocidade e, conseqüentemente, por mais amizade e inimizade que provoque, como se trata de concorrência personificada, os princípios em que se baseia são constantemente reafirmados.

A única esfera em que o recrutamento foi despersonificado, no Brasil, no que tange à titulação escolar, foi a do ingresso nos 
cursos superiores, em fase recente, portanto já no final do período abarcado pelas trajetórias consideradas. Porém, ainda não se dispõe de indicações suficientes sobre os efeitos disso e da expansão recente da oferta de títulos escolares nas estruturas profissionais que estiveram, até então, assentadas em relações de reciprocidade.

CORADINI, O. L.: 'Grandes famílias e elite profissional na medicina no Brasil'. História, Ciências, Satíde - Manguinbos, III (3) 425-466, nov. 1996-fev. 1997.

Este artigo tem como principal objetivo a apresentação das bases sociais e ideológicas da seleção da elite médica no Brasil. Em primeiro lugar, pretende introduzir uma discussão conceitual relativa às relações de reciprocidade em instituições oficiais no Brasil, tendo como base empírica a Academia Nacional de Medicina. Em segundo lugar, fundamentado em algumas trajetórias representativas dos componentes desta academia, em diferentes períodos de sua existência, procura caracterizar um padrão geral de concepção e práticas sociais e políticas. Por fim, busca examinar os significados do título escolar enquanto recurso para ascensão social e recrutamento de elites no Brasil.

PALAVRAS-CHAVE: elite médica, trajetória profissional, instituições médicas, origem familiar, poder político.

\section{REFERÊNCIAS BIBLIOGRÁFICAS}

\section{Bibliografia de referência conceitual}

Badie, B. e Hermet, G. Politique comparée. 1990 Paris, PUF.

Banton, $M$. 1980 Antropología de las sociedades complejas. Madri, Alianza.

Boissevain, J. 1977

Boissevain, J. mar. 1966

'Factions, parties and politics in a Maltese village'. Em S. W. Schmidt et al. (orgs.), Friends, followers and factions: a reader in political clientelism. Berkeley, University of California Press.

Bourdieu, P. 1989

Bourdieu, P. e

Saint Martin, M. set. 1987

Bourdieu, P. 1984

Bourdieu, P. 'Patronage in Sicily'. Man, 1:1.

La noblesse d'état: grandes écoles et esprit de corps. Paris, Minuit.

'Agrégation et ségrégation des grandes écoles et le champ du pouvoir'. Actes de la Recherche en Sciences Sociales, 69.

\section{Homo Academicus.} Paris, Minuit. fev.-mar. 1981

'La representation politique: éléments pour une théorie du champ politique'.

Bourdieu, P. $1980 a$

Bourdieu, P. 31 jan. 1980b Actes de la Recherche en Sciences Sociales, 36/37, pp. 3-24.

Le sens pratique. Paris, Minuit.

'Le capital social'.

Bourdieu, $\mathrm{P}$. Actes de la Recherche en Sciences Sociales.

'Le champ scientifique'. jun. 1976 Actes de la Recherche en Sciences Sociales, 2-3. 
Bourdieu, P. mai. 1975

Bourdieu, P. e Boltanski, L. 1975

Bourdieu, P. 1974

Charle, C. 1987

Cole, J. W. e Wolf, E. R. 1971

Collins, R. 1979

Davis, $\mathrm{J}$ 1983

Elias, N. 1987

Foucault, $M$ 1987

Freidson, E. 1984

Gellner, E. et al. 1985

Léonard, J. 1981

Maxwell, W. E. nov. 1975

Oszlak, $\mathrm{O}$. jan.-mar. 1992

Pécaut, D. 1990

Saint Martin, M. jan. 1980

Schmidt, S. W. et al. (orgs.) 1977

Weisz, G. set. $1988 \mathrm{a}$

Weisz, G. $1988 \mathrm{~b}$

Wolf, E. R. 1980
'La specificité du champ scientifique et les conditions sociales du progrès de la raison'. Sociologie et Sociétés, VII:1.

'Le titre et le poste: rapports entre le systéme de production et le systéme de reproduction'. Actes de la Recherche en Sciences Sociales, 2.

'Avenir de classe et causalité du probable'.

Actes de la Recherche en Sciences Sociales, XV.

Les elites de la Republique (1880-1900).

Paris, Fayard.

The hidden frontier: ecology and ethnicity in an Alpine Valley.

Nova York, Academic Press.

The credential society: an historical sociology of edication and stratification. San Diego, Academic Press.

Antropología de las sociedades mediterráneas.

Barcelona, Anagrama.

A sociedade de corte.

Lisboa, Estampa.

O nascimento da clínica.

Rio de Janeiro, Forense Universitária.

La profession médicale.

Paris, Payot.

Patronos y clientes.

Madri, Jucar.

La médicine entre les ponvoirs et les savoirs.

Paris, Aubier Montaigne

'Modernization and mobility into the patrimonial medical elite in Thailand'. American Journal of Sociology, 81:3

'Políticas públicas e regimes políticos: reflexões a partir de algumas experiências latino-americanas'. Revista de Administração Püblica.

Os intelectuais e a política no Brasil: entre o povo e a nação.

São Paulo, Ática.

'Une grande famille'. Actes de la Recherche en Sciences Sociales, 31.

Friends, followers and factions: a reader in political clientelism.

Berkeley, University of California Press.

'Les transformations de l'élite médicale en France'.

Actes de la Recherche en Sciences Sociales, 74.

'The self-made mandarin: the éloges of French Academy of Medicine, 1824-47'. History of Science, XXVI.

'Relaciones de parentesco, de amistad y de patronazgo en las sociedades complejas'. Em M. Banton (org.), Antropología de las sociedades complejas. Madri, Alianza.

\section{Bibliografia e documentos utilizados como fontes de informação}

Aguiar, M. S.

'Conversa com Pedro Nava - 1982'.

jan.-jul. 1994

Boletim/CESP, 14:17. 
Araújo, C. de S

s. d.

Arrigucci Jr., D. 1987

Azevedo, F. de (org.) s. d.

Carvalho, J. M. de 1981

Coradini, O. L. 1994

Fernandes, R. 1982

Fernandes, R. 1980

Freitas, D. G. de 1984

Grynszpan, M. out. 1990

Hall, $\mathrm{O}$. mar. 1948

IHGB 1942

Lacaz, C. da S. 1963, 1966, 1971, 1977

Moacyr, P. A. $1936,1937,1938$

Nava, $\mathrm{P}$ 1987

Nava, P. 1986

Nava, $P$ 1983

Nava, $P$. 1976

Nava, $\mathrm{P}$ 1973

Quintella, M. M. D. 1984

Salles, P. e Gama, G. jan.-ago. 1987

Santos Filho, L. 1991

Santos Filho, L. de C. 1984

Santos Filho, L. 1967
L'influence française sur la culture brésilienne: sur la pharmacie et la médicine, en particulier. Rio de Janeiro, Olimpia.

'Mobile de memória'. Em Enigma e comentário' ensaios sobre literatura e experiência. São Paulo, Companhia das Letras.

As ciências no Brasil.

Melhoramentos, 2 vols.

A construção da ordem: a elite política imperial. Brasília, Edunb.

A formação da elite médica, a institucionalização e a "crise da medicina" no Brasil. Relatório de pesquisa para o CNPq, Porto Alegre. (mimeo.)

O conselheiro Jobim o o espírito da medicina em seu tempo. Brasília, Ed. do Senado Federal.

'José Martins da Cruz Jobim - um fundador da Academia Nacional de Medicina'. Revista do Instituto Histórico e Geográfico Brasileiro, v. 327.

'Médicos e cirurgiões da Imperial Câmara de D. Pedro II'. Em IHGB, Anais do Congresso de História do Segundo Reinado, vol. 1.

'Os idiomas da patronagem: um estudo da trajetória de Tenório Cavalcanti'. Revista Brasileira de Ciências Socias, 14:5.

'The stages of a medical career'.

The American Jomrnal of Sociology, LIII:5.

Anais do Segundo Congresso de História Nacional (7 a 14 de abril de 1931). Rio de Janeiro.

Villos da medicina brasileira. Rio de Janeiro, Academia Nacional de Medicina, 4 vols.

A instrução no Império: subsidios para a bistória da educação no Brasil. São Paulo, Cia. Ed. Nacional, 3 vols.

Galo-das-trevas (as doze velas imperfeitas). 4a ed., Rio de Janeiro, Nova Fronteira. Memórias.

Balão cativo. 4a ed., Rio de Janeiro, Nova Fronteira. Memórias.

O cirio perfeito. Rio de Janeiro, Nova Fronteira. Memórias.

Chão de ferro. Rio de Janeiro, José Olympio. Memórias.

Baii de ossos. $2^{\mathbf{n}}$ ed., Rio de Janeiro, José Olympio/Sabiá. Memórias.

'Cultura e poder ou espelho, espelho meu: existe alguém mais culto do que eu?'. Em S. Miceli (org.), Estado e cultura no Brasil. São Paulo, Difel.

'Pedro Nava'. Anais da Faculdade de Medicina da UFMG, 36:1-2.

História geral da medicina brasileira.

São Paulo, Hucitec/Edusp.

'O médico republicano no Segundo Reinado'. Em IHGB, Anais do Congresso de História do Segundo Reinado, vol. 1.

'Medicina no período imperial'. Em S. B. de Holanda (org.), História geral da civilização brasileira. São Paulo, Difel. 
Santos Filho, L. 1947

Santos, I. B. dos s. d.

Sattamini-Duarte, O. 1957

Schwartzman, S. 1983

Sodré, A. 1947

Torres, J. C. de O. 1965

Torres, J. C. de O. 1964
História da medicina no Brasil. São Paulo, Brasiliense, 2 vols.

Vultos e fatos da medicina brasileira. Rio de Janeiro, Pongetti.

Um médico do Império (O doutor Torres Homem) 1837-1887. Rio de Janeiro, Pongetti.

'A pesquisa científica no Brasil: matrizes culturais e institucionais'. Em E. L. Gonçalves (org.), Pesquisa médica. São Paulo, CNPq.

'Um médico da monarquia'. Revista do IHGB, vol. 195.

O conselbo de Estado. Rio de Janeiro, GRD.

A democracia coroada: teoria política do Império do Brasil. Petrópolis, Vozes.

\section{Arquivos e periódicos}

Arquivos da Academia Nacional de Medicina

Boletim da Academia Nacional de Medicina

Brazil Médico

Gazeta Médica

Jornal do Commercio

O Globo

O Hospital

Revista do Instituto Histórico e Geográfico Brasileiro (IHGB)

Tribuına Médica

Recebido para publicação em jullıo de 1996. 